\title{
REVISIONISMO HISTÓRICO Y RACISMO EN LA JURISPRUDENCIA CONSTITUCIONAL: LOS LÍMITES DE LA LIBERTAD DE EXPRESIÓN (A PROPÓSITO DE LA STC 235/2007)
}

\author{
POR \\ GÖRAN ROLLNERT LIERN \\ Profesor Titular de Derecho Constitucional \\ Universidad de Valencia (Estudio General)
}

\section{INTRODUCCIÓN Y ANTECEDENTES: LA MÁXIMA AMPLITUD DEL ÁMBITO DE LA LIBERTAD IDEOLÓGICA Y LAS SSTC 214/1991 Y 176/1995}

La reciente sentencia del Tribunal Constitucional 235/2007, de 7 de noviembre, ha venido a replantear la cuestión de los límites de la libertad de expresión en los casos extremos en los que las ideas y opiniones difundidas entran en abierta contradicción con los valores constitucionales, en particular con la dignidad y la igualdad, por responder a presupuestos ideológicos racistas que se exteriorizan mediatamente a través de la negación o justificación del genocidio perpetrado en los campos de concentración nazis durante la Segunda Guerra Mundial. Y se habla de replanteamiento porque el Tribunal Constitucional ya se había pronunciado sobre esta materia en dos sentencias anteriores muy conocidas - las SSTC 214/1991, de 11 de noviembre y 176/1995, de 11 de diciembre- en las que había matizado su doctrina general sobre la libertad de expresión y a las que haremos referencia previa para analizar la trascendencia de este nuevo pronunciamiento jurisdiccional. 
La sentencia en cuestión ha declarado parcialmente inconstitucional la sanción penal de la difusión de ideas o doctrinas que nieguen los delitos de genocidio y, por otra parte, ha considerado constitucionalmente legítima la punición de las ideas o doctrinas que justifiquen dichos delitos siempre que el precepto del Código Penal (CP en adelante) en cuestión (art. 607.2) se interprete en los términos que establece el fundamento jurídico 9 de la misma, todo ello con cuatro votos particulares discrepantes. El fallo ha sido dictado en la cuestión de inconstitucionalidad planteada por la Sección Tercera de la Audiencia Provincial de Barcelona al conocer del recurso de apelación contra la primera sentencia dictada en España por los delitos de provocación a la discriminación (art. 510.1 CP) y difusión de ideas o doctrinas negacionistas o justificadoras del genocidio (art. 607.2 CP) en la que se condenó al propietario de una librería barcelonesa especializada, según los hechos probados, en la difusión de material negacionista o revisionista del holocausto judío ${ }^{1}$.

Es conocida y numerosísima la jurisprudencia constitucional sobre el contenido y alcance de la libertad de expresión pero, entre toda ella, la STC 20/1990, de 15 de febrero, ocupa un lugar muy destacado por cuanto no sólo se refiere a un supuesto en el que el ejercicio de la libertad de expresión implica simultáneamente una manifestación externa de la libertad ideológica ${ }^{2}$ (como el

${ }^{1}$ Según la selección de hechos probados de la sentencia de instancia, «el acusado Pedro Varela Geiss, mayor de edad y sin antecedentes penales, actuando en su condición de titular y director de la librería Europa... ha venido procediendo de forma habitual y continuada, con posterioridad al mes de junio de 1996, y a sabiendas de la entrada en vigor en España de la actual legislación penal en esta materia, a la distribución, difusión y venta de todo tipo de materiales en soporte documental y bibliográfico, libros, publicaciones, cartas, carteles, etc..., en los que de forma reiterada e inequívocamente vejatoria para el grupo social integrado por la comunidad judía, se negaba la persecución y genocidio sufridos por dicho pueblo durante el periodo histórico de la Segunda Guerra Mundial, masacre colectiva programada y ejecutada por los responsables de la Alemania nazi que gobernaron en la época del III Reich. La inmensa mayoría de dichas publicaciones contenían textos en los que se incita a la discriminación y al odio hacia la raza judía, considerándoles seres inferiores a los que se debe exterminar como 'a las ratas'»; «en la citada librería se vendían también publicaciones relativas a Arte, Historia y Mitología religiosa, pero su número era manifiestamente testimonial en comparación con las obras dedicadas al revisionismo del holocausto judío. El público habitual del establecimiento eran jóvenes caracterizados por su afinidad con las ideologías defensoras de la violencia como método de resolución de conflictos. Dichas publicaciones y material estaban a la venta al público y se exportaban por correo a multitud de clientes en Alemania, Austria, Bélgica, Brasil, Chile, Argentina y Sudáfrica, entre otros países. La librería Europa figuraba en toda la correspondencia remitida y recibida como editora y distribuidora del material comercializado". Junto a ello se recogen algunos extractos de los contenidos de algunos de los libros ocupados negando el genocidio o justificando el mismo, o bien con afirmaciones incitando al exterminio" (Antecedente 2, STC 235/2007). 
caso que nos ocupa de difusión de ideas o doctrinas racistas o revisionistas) sino que es la sentencia en la que con mayor profundidad se ha analizado desde una perspectiva general el ámbito constitucionalmente protegido por la libertad ideológica cuando la misma se proyecta a través de la libertad de expresión.

Pues bien, la STC 20/1990 partía de una afirmación de principio - posteriormente reiterada en el ATC 40/1999, de 22 de febrero, FJ 2-cual es la de «[...] la máxima amplitud con que la libertad ideológica está reconocida en el artículo 16.1 CE por ser fundamento, juntamente con la dignidad de la persona y los derechos inviolables que le son inherentes, según se proclama en el artículo 10.1, de otras libertades y derechos fundamentales [...]» (FJ 4); la misma idea se reiteró en el FJ 5 de la misma sentencia según el cual «[...] la libertad ideológica, indisolublemente unida al pluralismo político que, como valor esencial de nuestro ordenamiento jurídico propugna la $\mathrm{CE}$, exige la máxima amplitud en el ejercicio de aquella [...]». Esta «mayor amplitud con que la CE configura el ámbito de aquel derecho" (FJ 3) tiene como principal consecuencia que el ámbito constitucionalmente protegido por la libertad ideológica se extiende, según la misma sentencia, al ejercicio de la misma «[...] no sólo en lo coincidente con la CE y el resto del ordenamiento jurídico, sino también en lo que resulte contrapuesto a los valores y bienes que en ellos se consagran, excluida siempre la violencia para imponer los propios criterios, pero permitiendo la libre exposición de los mismos en los términos que impone una democracia avanzada» (FJ 5), posición que vendría a coincidir con la opinión mayoritaria de la doctrina en el sentido de que la libertad ideológica ampara el derecho a profesar una ideología contraria a la Constitución, excluyéndose lógicamente de tal cobertura la imposición de la misma por medios anticonstitucionales ${ }^{3}$. En definitiva, del juego

2 Sobre la relación entre la libertad de expresión y la libertad ideológica puede consultarse G. ROLLnert Liern, La libertad ideológica en la jurisprudencia del Tribunal Constitucional (19802001), Centro de Estudios Políticos y Constitucionales, Madrid, 2002, págs. 173-180. A su vez, acerca de la trascendencia que tiene la STC 20/1990 sobre los límites aplicables a las libertades ideológicas y de expresión, G. ROLLNERT LIERN, «Los límites de la libertad ideológica y de la libertad de expresión en la jurisprudencia constitucional española», en M. CARBONELL (comp.), Problemas contemporáneos de la libertad de expresión, Porrúa, México, 2005, págs. 258-259 y 268-282.

3 Entre otros, J. M. Serrano Alberca, «Artículo 16» en Comentarios a la Constitución, F. Garrido Falla y otros, 2. ${ }^{a}$ ed., Cívitas, Madrid, 1985, pág. 307; y A. Moreno GarCíA, «Significado constitucional de la libertad ideológica» en Anuario de derecho constitucional y parlamentario, Asamblea Regional de Murcia-Universidad de Murcia, núm. 7 (1995), págs. 109-113. Matizadamente en contra, M. Martínez Sospedra para quien, a la vista de la STC 214/1991, «si bien la libertad de expresión protege incluso en el caso de que mediante ella se defiendan ideologías antidemocráticas, la protección constitucional cesa en aquellos casos en los que el derecho del artícu- 
combinado de la libertad ideológica con la libertad de expresión como su principal manifestación externa resultaría un derecho a la disidencia ideológica pacífica — «el disenso ideológico no violento» del que habla la STC 74/1991, de 8 de abril (FJ 6) - respecto de los valores y principios constitucionales.

Sin embargo, la claridad de esta doctrina que admitió como constitucionalmente legítima la libre exposición pacífica de las creencias contrarias a los valores y bienes constitucionales se vió en cierta medida enturbiada por dos sentencias posteriores (SSTC 214/1991 y 176/1995') que se pronunciaron acerca del denominado «revisionismo histórico» respecto de la Segunda Guerra Mundial y, en concreto, respecto de los asesinatos en masa en los campos de concentración de la Alemania nacionalsocialista. En la medida que la STC 235/2007 reitera los argumentos fundamentales de las mismas y viene a clarificar algunos aspectos de su fundamentación jurídica, es imprescindible una referencia a ellas como punto de partida de la exposición del actual estado de la cuestión en la jurisprudencia de nuestro Alto Tribunal.

La primera de dichas sentencias, la STC 214/19915, comenzó por reconocer, en abstracto, la legitimidad constitucional del «revisionismo histórico» al amparo de la libertad ideológica al declarar que «[...] del examen de la totalidad de declaraciones del demandado publicadas, no sólo de las parcialmente transcritas en el escrito de demanda, es indudable que las afirmaciones, dudas y opiniones acerca de la actuación nazi con respecto a los judíos y a los campos de concentración, por reprobables o tergiversadas que sean - y ciertamente lo son al negar la evidencia de la historia-, quedan amparadas por el derecho a la libertad de expresión (artículo 20.1 CE), en relación con el derecho a la libertad ideológica (artículo $16 \mathrm{CE}$ ), pues, con independencia de la valoración que de las mismas se

lo 20.1 a) y del artículo 16.1 CE se ejerce en contradicción radical con los valores de igualdad y dignidad que constituyen el núcleo fundamental del orden de valores constitucional» (Libertades públicas, Fundación Universitaria San Pablo CEU, volumen I, Valencia, 1993, págs. 133 y 244245). 364.

${ }^{4}$ Un análisis más detallado de estas sentencias en G. ROLLnERT Liern, ob. cit., págs. 348-

5 Para un estudio detallado sobre esta sentencia, vid. M. MARTínEz SOSPEDRA, «No todas las ideas son respetables. Racismo y Nacionalsocialismo en el Estado constitucional democrático (Acerca de la sentencia del Tribunal Constitucional 214/1991, de 11 de noviembre.-Caso Friedman-)», en Revista General de Derecho, núm. 585 (1993), págs. 5785-5804. Un comentario más breve a la misma puede leerse en J. M. TAMARIT SuMALla, "Artículo 510", en Comentarios a la Parte Especial del Código Penal, G. Quintero Olivares (dir.) y otros, Aranzadi, Madrid, 1996, págs. 1434-1435. También puede verse al respecto la crítica de F. SANTAOLALLA LÓPEZ en "Jurisprudencia constitucional sobre la libertad de expresión: una valoración", en Revista de Administración Pública, núm. 128 (1992), págs. 198-199 y 205-208. 
haga, lo que tampoco corresponde a este Tribunal, sólo pueden entenderse como lo que son: opiniones subjetivas e interesadas sobre acontecimientos históricos» (FJ 8).

No obstante lo anterior, en el mismo FJ entendió el juez constitucional que en aquel caso concreto las declaraciones del demandado sobrepasaron el ámbito de la libertad de expresión y no gozaron por tanto de la prevalencia que sobre el derecho al honor les atribuye la doctrina constitucional; argumentó el Tribunal que las afirmaciones efectuadas, valoradas en su conjunto, son ofensivas para el pueblo judío por cuanto contienen connotaciones racistas y antisemitas que no pueden ser interpretadas sino como una incitación antijudía atentatoria contra el derecho al honor de la actora y del pueblo judío en general.

La contradicción con la doctrina general inicialmente expuesta acerca de la máxima amplitud de la libertad ideológica surge cuando el Tribunal rechaza la legitimidad constitucional de las afirmaciones del demandado por cuanto las mismas son calificadas de manifestaciones de carácter racista y xenófobo contrarias a la dignidad humana que «[...] como rango o categoría de la persona como tal $[. .$.$] no admite discriminación alguna por razón de nacimiento, raza,$ sexo, opiniones o creencias». Consideró el Tribunal que «[...] las expresiones y aseveraciones proferidas por el demandado desconocen la efectiva vigencia de los valores superiores del ordenamiento, en concreto del valor de igualdad consagrado en el artículo 1.1 CE, en relación con el artículo $14 \mathrm{CE}$, por lo que no pueden considerarse como constitucionalmente legítimas» $(\mathrm{FJ} 8)^{6}$.

Parece rechazarse así en esta sentencia la licitud constitucional de la expresión pacífica de ideas contrarias a valores constitucionales como la dignidad humana y la igualdad, entrando así en directa oposición con la doctrina sentada en el FJ 5 de la STC 20/1990 anteriormente comentada según la cual «[...] la libertad ideológica [...] exige la máxima amplitud en el ejercicio de aquella y, naturalmente, no sólo en lo coincidente con la Constitución y con el resto del ordenamiento jurídico, sino también en lo que resulte contrapuesto a los valores y bienes que en ella se consagran, excluida siempre la violencia para imponer los

${ }^{6}$ La doctrina española ha valorado desigualmente la posición adoptada por el TC en la sentencia. 214/1991. Vid. M. MARTínez SOSPEDra, ob. cit., págs. 5794-5796; P. LAURENZO CAPELlO, «Marco de protección jurídico-penal del derecho a no ser discriminado. Racismo y xenofobia», en Libertad ideológica y derecho a no ser discriminado, en M. L. MAQUEDA ABREU (dir.), Cuadernos de Derecho Judicial, núm. I (1996), Escuela Judicial/Consejo General del Poder Judicial, pág. 221; A. Gallego ANabitarte, Derechos fundamentales y garantías institucionales: análisis doctrinal y jurisprudencial: (derecho a la educación; autonomía local; opinión pública), Cívitas-Ediciones de la Universidad Autónoma de Madrid, Madrid, 1994, págs. 206-207; J. M. Morales ArroYo, ob. cit., págs. 297-298; y F. SANTAOLALLA LÓPEZ, op. cit. pág. 207. 
propios criterios, pero permitiendo la libre exposición de los mismos en los términos que impone una democracia avanzada». Insistiendo en la misma idea, afirmó el juez constitucional en la sentencia que comentamos que las libertades ideológica y de expresión «[...] no garantizan, en todo caso, el derecho a expresar y difundir un determinado entendimiento de la historia o concepción del mundo con el deliberado ánimo de menospreciar y discriminar, al tiempo de formularlo, a personas o grupos por razón de cualquier condición o circunstancia personal, étnica o social, pues sería tanto como admitir que, por el mero hecho de efectuarse al hilo de un discurso más o menos histórico, la $\mathrm{CE}$ permite la violación de uno de los valores superiores del ordenamiento jurídico, como es la igualdad (artículo 1.1 CE) y uno de los fundamentos del orden político y de la paz social: la dignidad de la persona (artículo 10.1 CE)» (FJ 8).

Con posterioridad, una segunda sentencia — la STC 176/19957— volvió a pronunciarse sobre la cuestión partiendo igualmente de una interpretación amplia de la libertad de expresión del pensamiento — «libertad de pensamiento o ideológica, libertad de expresión o de opinión» dice la propia sentencia (FJ 2) - y relativizando cualquier discusión sobre hechos históricos: «Es evidente que al resguardo de la libertad de opinión cabe cualquiera, por equivocada o peligrosa que pueda parecer al lector, incluso las que ataquen al propio sistema democrático. La Constitución — se ha dicho- protege también a quienes la niegan. En consecuencia, no se trata aquí de discutir la realidad de hechos históricos, como el Holocausto. La libertad de expresión comprende la de errar $y$ otra actitud al respecto entra en el terreno del dogmatismo, incurriendo en el defecto que se combate, con mentalidad totalitaria. La afirmación de la verdad absoluta, conceptualmente distinta de la veracidad como exigencia de la información, es la tentación permanente de quienes ansían la censura previa, de la que más abajo habrá ocasión de hablar. Nuestro juicio ha de ser en todo momento ajeno al acierto o desacierto en el planteamiento de los temas o a la mayor o menor exactitud de las soluciones propugnadas, desprovistas de cualquier posibilidad de certeza absoluta o de asentimiento unánime por su propia naturaleza, sin formular en ningún caso un juicio de valor sobre cuestiones intrínsecamente discutibles, ni compartir o discrepar de opiniones en un contexto polémico» (FJ 2).

7 Sobre esta sentencia puede consultarse C. CONDE-PUMPIDO TOURÓN, «La sanción penal de la discriminación; especial referencia a la discriminación por razón de enfermedad y al nuevo delito de discriminación en el trabajo», en M. L. MAQUEDA ABREU (dir.), Libertad ideológica y derecho a no ser discriminado, Cuadernos de Derecho Judicial, núm. I (1996), Escuela Judicial/Consejo General del Poder Judicial, págs. 296-300; y P. LaURenZo Copello, ob. cit., págs. 262 y 263. 
Sin embargo, también en este caso esta concepción inicialmente amplia del ámbito de la libertad ideológica como comprensiva de las manifestaciones hostiles al propio régimen democrático se ve posteriormente recortada en virtud de la misma operación intelectual efectuada en la STC 214/1991: en la medida que el Tribunal considera que la finalidad global de la obra es humillar y ofender al pueblo judío - por hallarse latente en ella un concepto peyorativo de la etnia judía-, las manifestaciones efectuadas por los autores son consideradas consecuencia de «una actitud racista contraria al conjunto de valores protegidos constitucionalmente» $y$, en cuanto tales, incitativas directa o subliminalmente, según los casos, a la violencia y al odio racial en contradicción con la prohibición contenida en el art. 20.2 del Pacto Internacional de Derechos Civiles y Políti$\cos ^{8}$. Concluye el juez constitucional que «la apología de los verdugos, glorificando su imagen y justificando sus hechos, a costa de la humillación de sus víctimas no cabe en la libertad de expresión como valor fundamental del sistema democrático que proclama nuestra Constitución. Un uso de ella que niegue la dignidad humana, núcleo irreductible del derecho al honor en nuestros días, se sitúa por sí mismo fuera de la protección constitucional (SSTC 170/1994 y 76/1995)» (FJ 5).

En definitiva, también en esta segunda sentencia el Tribunal Constitucional situó fuera de la protección constitucional el ejercicio de la libertad ideológica en sentido contrario a los valores constitucionales y particularmente a su concepción de la dignidad humana como radicalmente incompatible con la discriminación racial.

A la vista de lo expuesto, puede considerarse que existe una contradicción aparentemente irresoluble entre la STC 20/1990 —que admitió la disidencia ideológica pacífica frente a los valores constitucionales-y las SSTC 214/1991 y 176/1995 que parecen negar la posibilidad de que la libertad ideológica se utilice para atacar, mediante la palabra, valores constitucionalmente consagrados como la igualdad y la dignidad humanas ${ }^{9}$. Es absolutamente contradictorio afirmar en la STC 20/1990 que la libertad ideológica alcanza su máxima amplitud también en lo que su ejercicio resulte contrapuesto a los bienes y valores consagrados en la Constitución y el resto del ordenamiento jurídico (FJ 5)

${ }^{8}$ Según el art. 20.2 del Pacto Internacional de Derechos Civiles y Políticos, de 19 de diciembre de 1966, «toda apología del odio nacional, racial o religioso que constituya incitación a la discriminación, la hostilidad o la violencia estará prohibida por la Ley» (FJ 5).

9 La conveniencia de que dicha doctrina tenga carácter excepcional ha sido señalada por J. M. Morales ArROYO, ob. cit., nota 19, pág. 297. No obstante, la STC 176/1995 vino a consolidar la doctrina anteriormente sentada por la STC 214/1991. 
para señalar posteriormente en la STC 214/1991 que las expresiones del demandado no son constitucionalmente legítimas por cuanto desconocen la efectiva vigencia de los valores superiores del ordenamiento y, entre ellos, del principio de igualdad $\left(\mathrm{FJ} 8^{10}\right)$ y en la STC 176/1995 negar a los autores del cómic la protección constitucional de la libertad de expresión por usar de ella para negar la dignidad humana y mantener una actitud contraria a los valores protegidos constitucionalmente (FJ 5). A este respecto, cabe decir que el Tribunal acierta al considerar que en ambos supuestos de hecho las expresiones utilizadas, desde la interpretación y valoración que de las mismas efectúa el juez constitucional, sobrepasaron los límites de la libertad de expresión pero no precisamente por ser contrarias a los valores constitucionales sino, en ambos casos, por atentar contra el derecho al honor del pueblo judío y equipararse por tanto a los insultos y a los apelativos formalmente injuriosos como límite insalvable de la libertad de expresión, según la conocida doctrina de la STC 105/1990, de 6 de junio ${ }^{11}$.

\section{LA STC 235/2007 Y SUS MIMBRES ARGUMENTALES}

En el ínterin entre la sentencia 214/1991 y la sentencia $176 / 1995^{12}$ se aprobó la Ley Orgánica 11/1995, de 11 de mayo, que modificó el Código Penal de

${ }^{10}$ La contradicción ínsita en el FJ 8 de la STC 214/1991 ha sido señalada por F. Santaolalla López para quien el Tribunal, después de declarar amparadas por las libertades de expresión e ideológica las declaraciones del demandado - «[...] las opiniones racistas pueden provocar un abierto rechazo, pero en la medida que son exposición pacífica del pensamiento, están amparadas por la libertad de expresión»-, «[...] acto seguido el TC incide, a través de una pobre argumentación, en un sorprendente cambio de postura, que le lleva a dictaminar la ilicitud de estas opiniones, en cuanto contrarias al derecho al honor de la demandante y de las personas que estuvieron internadas en los campos nazis. [...] Semejante consideración no sólo contradice la anteriormente transcrita sino que supone un apartamiento del defendido carácter prioritario de las libertades de expresión e información. Ahora parece que priman las restricciones derivadas de otros derechos constitucionales, cuando antes se subrayaba la subordinación de estos últimos. La piedra de toque de esta mutación reside, claro está, en el contenido de las opiniones en cuestión» (op. cit., pág. 199).

${ }_{11}$ «No cabe duda de que la emisión de apelativos formalmente injuriosos en cualquier contexto, innecesarios para la labor informativa o de formación de la opinión que se realice supone un daño injustificado a la dignidad de las personas o al prestigio de las instituciones, teniendo en cuenta que la Constitución no reconoce un pretendido derecho al insulto, que sería por lo demás incompatible con la dignidad de la persona que se proclama en el art. 10.1 del Texto fundamental» (STC 105/1990, FJ 8).

12 Cabe destacar que aunque la STC 176/1995 se dictó con posterioridad a la entrada en vigor de la Ley Orgánica 11/1995, de 11 de mayo, que introdujo en el Código Penal de 1973 los 
1973 para tipificar el delito de apología de genocidio, justificándose dicha reforma por la Exposición de Motivos en el cumplimiento de las obligaciones adquiridas por España en virtud de la ratificación de tratados internacionales sobre la materia ${ }^{13}$, citándose expresamente la STC 214/1991 para argumentar que dichas obligaciones «no pueden verse limitadas por las libertades ideológica y de expresión». El vigente Código Penal de 1995 mantuvo la tipificación penal de las mismas conductas y amplió los tipos penales relativos a la discriminación ${ }^{14}$, siendo éste el contexto en el que se enmarca el art. 607.2 del Código Penal respecto al cual se promovió la cuestión de inconstitucionalidad ahora resuelta por la STC 235/2007.

$\mathrm{El}$ art. 607.2 establece que «la difusión por cualquier medio de ideas o doctrinas que nieguen o justifiquen los delitos tipificados en el apartado anterior de este artículo [i.e., delitos de genocidio ${ }^{15}$, o pretendan la rehabilitación de regí-

delitos de apología del genocidio (art. 137 bis) y provocación o incitación a la discriminación (art. 165 ter), la misma resolvió un recurso de amparo contra una sentencia de instancia de 1990 que condenó al recurrente por un delito de injurias graves del art. 458 CP, no existiendo en 1990 ni el delito de apología del genocidio ni el de provocación o incitación a la discriminación.

13 Se citan al respecto en la Exposición de Motivos el Convenio de Nueva York, de 9 de diciembre de 1948 para la prevención y la sanción del delito de genocidio (vid. arts. I y III), y el Convenio internacional sobre la eliminación de todas las formas de discriminación racial, de 21 de diciembre de 1965 (vid. art. 4).

14 Vid. en este sentido, P. Laurenzo Copello, ob. cit., págs. 219-228 y 238-282. Como otras medidas penales antidiscriminatorias, se incorporó la agravante genérica de actuar por motivos racistas, antisemitas u otra clase de discriminación (art. 22.4) y se amplió el elenco de asociaciones ilícitas a las que promuevan la discriminación, el odio o la violencia por razón de la pertenencia a una etnia, raza o nación — art. 515.5 — frente a la regulación anterior (art. 173.4) que se limitaba a considerar ilícitas las asociaciones promotoras o incitativas a la discriminación racial.

15 Según el art. 607.1 CP, «los que, con propósito de destruir total o parcialmente a un grupo nacional, étnico, racial o religioso, perpetraren alguno de los actos siguientes, serán castigados:

1. ${ }^{\circ}$ Con la pena de prisión de quince a veinte años, si mataran a alguno de sus miembros. $\mathrm{Si}$ concurrieran en el hecho dos o más circunstancias agravantes, se impondrá la pena superior en grado.

2. ${ }^{\circ}$ Con la prisión de quince a veinte años, si agredieran sexualmente a alguno de sus miembros o produjeran alguna de las lesiones previstas en el artículo 149.

3. ${ }^{\circ}$ Con la prisión de ocho a quince años, si sometieran al grupo o a cualquiera de sus individuos a condiciones de existencia que pongan en peligro su vida o perturben gravemente su salud, o cuando les produjeran algunas de las lesiones previstas en el artículo 150.

4. ${ }^{\circ}$ Con la misma pena, si llevaran a cabo desplazamientos forzosos del grupo o sus miembros adoptaran cualquier medida que tienda a impedir su género de vida o reproducción, o bien trasladaran por la fuerza individuos de un grupo a otro.

5. ${ }^{\circ}$ Con la de prisión de cuatro a ocho años, si produjeran cualquier otra lesión distinta de las señaladas en los números 2 y 3 de este apartado». 
menes o instituciones que amparen prácticas generadoras de los mismos, se castigará con la pena de prisión de uno a dos años» y el Tribunal Constitucional ha circunscrito la cuestión de inconstitucionalidad al primer inciso del citado artículo - esto es, a la difusión de ideas o doctrinas que nieguen o justifiquen el genocidio- atendiendo al objeto del proceso penal ante el tribunal de instancia y a la fundamentación jurídica del auto de planteamiento de la cuestión.

La Audiencia Provincial de Barcelona argumentó que, habida cuenta de que la conducta sancionada por el art. 607.2 CP es exclusivamente la de difundir ideas o doctrinas que nieguen o justifiquen los delitos de genocidio ${ }^{16}$, resulta evidente el conflicto entre esta norma penal, que sanciona la difusión de ideas y opiniones sobre determinados hechos históricos, y el derecho a la libertad de expresión constitucionalmente consagrado en el art. 20.1 CE, a lo que añadió la naturaleza difusa del bien jurídico protegido (evitar que se cree un clima favorecedor de conductas discriminatorias) que, a juicio del órgano cuestionante, no es merecedor de protección penal en la medida en que, además de su carácter difuso, supone un límite al derecho a la libertad de expresión.

$\mathrm{El}$ análisis de la ratio decidendi del fallo permite distinguir varios elementos concurrentes en su línea argumental, siendo merecedores todos ellos de consideración detallada.

\section{La doctrina constitucional sobre la libertad de expresión y el rechazo de la «democracia militante»}

Comienza el Alto Tribunal su razonamiento discursivo en el FJ 4 compilando su temprana y reiterada jurisprudencia ${ }^{17}$ acerca de la naturaleza institucional de la libertad de expresión al ser garantía de la formación y existencia de una opinión pública libre y, por ello, uno de los pilares de una sociedad libre y democrática y remitiendo asimismo a la doctrina sentada por el Tribunal Europeo de Derechos Humanos desde la Sentencia Handyside c. Reino Unido, de 7 de diciembre de 1976: «la libertad de expresión constituye uno de los funda-

16 «A este respecto, razona la Sala que el art. 607.2 CP constituye un tipo penal autónomo que no puede integrarse con la definición que de la apología del delito ofrece el art. $18 \mathrm{CP}$ ni, en consecuencia, sanciona la apología de los delitos de genocidio ni tampoco la provocación a su comisión o la incitación al odio racial, al venir ya tipificadas estas conductas en otros preceptos del Código Penal (arts. 510, 515.5. ${ }^{\circ}, 519$ y 615 CP)» (Antecedente 3).

17 STC 6/1981 de 16 de marzo, FJ 3, recogido, entre otras, en las SSTC 20/1990, de 15 de febrero; 336/1993, de 15 de noviembre; 101/2003, de 2 de junio; y 9/2007, de 15 de enero. 
mentos esenciales de una sociedad democrática y una de las condiciones primordiales de su progreso y del desarrollo de cada uno».

A partir de ello y con apoyo expreso en las afirmaciones ya comentadas de las SSTC 214/1991 (FJ 8) y 176/1995 (FJ 2) que reconocen en abstracto la legitimidad constitucional de las opiniones que ataquen al sistema democrático y el amparo de la libertad de expresión a las afirmaciones, dudas y opiniones acerca de la actuación nazi con respecto a los judíos y a los campos de concentración, el juez constitucional afirma que «en nuestro sistema - a diferencia de otros de nuestro entorno- no tiene cabida un modelo de «democracia militante», esto es, un modelo en el que se imponga, no ya el respeto, sino la adhesión positiva al ordenamiento y, en primer lugar, a la Constitución» (FJ 4). Se descarta así la naturaleza beligerante de la democracia española mediante una remisión expresa a la STC 48/2003, de 12 de marzo (FFJJ 7 y 10) para establecer que la concepción garantista presente en nuestro ordenamiento constitucional «implica la necesidad de diferenciar claramente entre las actividades contrarias a la Constitución, huérfanas de su protección, y la mera difusión de ideas e ideologías. El valor del pluralismo y la necesidad del libre intercambio de ideas como sustrato del sistema democrático representativo impiden cualquier actividad de los poderes públicos tendente a controlar, seleccionar, o determinar gravemente la mera circulación pública de ideas o doctrinas».

Sobre esta base concluye el Tribunal con una de las afirmaciones de mayor relevancia contenidas en esta sentencia y sobre la que volveremos más adelante: «nuestro ordenamiento constitucional se sustenta en la más amplia garantía de los derechos fundamentales, que no pueden limitarse en razón de que se utilicen con una finalidad anticonstitucional [...]. El ámbito constitucionalmente protegido de la libertad de expresión no puede verse restringido por el hecho de que se utilice para la difusión de ideas u opiniones contrarias a la esencia misma de la Constitución - y ciertamente las que se difundieron en el asunto que ha dado origen a la presente cuestión de inconstitucionalidad resultan repulsivas desde el punto de vista de la dignidad humana constitucionalmente garantizada - a no ser que con ellas se lesionen efectivamente derechos o bienes de relevancia constitucional", y ello con independencia de que no toda idea expresada sea acreedora de respeto para la conciencia cívica de una sociedad abierta y democrática y de que la tolerancia, en cuanto principio democrático de convivencia que debe inspirar la educación ex art. 27.2 CE, no pueda equipararse sin más «con la indulgencia ante discursos que repelen a toda conciencia conocedora de las atrocidades perpetradas por los totalitarismos de nuestro tiempo». 


\section{Los límites de la libre transmisión de ideas: el "discurso del odio» y la aplicabilidad del art. 17 del Convenio Europeo de Derechos humanos con especial referencia a la jurisprudencia de Estrasburgo sobre revisionismo histórico y racismo}

Sin embargo, ese generoso reconocimiento de las libertades ideológica y de expresión «no implica que la libre transmisión de ideas, en sus diferentes manifestaciones, sea un derecho absoluto", afirma el Tribunal en el FJ 5 en el que viene a delimitar el ámbito constitucionalmente protegido de dicho derecho al ubicar fuera del mismo ${ }^{18}$ el insulto con carácter genérico y, específicamente, por nueva remisión a las SSTC 214/1991 y 176/1995, las manifestaciones, expresiones o campañas de carácter racista o xenófobo, la apología humillante para las víctimas del genocidio y los juicios ofensivos contra los judíos que, al hilo del negacionismo, supongan una incitación racista; se acude así otra vez a la doctrina constitucional anterior pero enfatizando en este caso la eficacia limitativa del valor superior de igualdad y de la dignidad humana - «el reconocimiento constitucional de la dignidad humana configura el marco dentro del cual ha de desarrollarse el ejercicio de los derechos fundamentales»— para privar de cobertura constitucional a las doctrinas racistas y negacionistas en cuanto que «atentan contra ese núcleo irreductible de valores esenciales de nuestro sistema constitucional»; en este sentido afirma, remitiéndose a la STC 214/1991 ${ }^{19}$, que «fundamentada en la dignidad (art. 10.1 y 2 CE) es, pues, el deliberado ánimo

18 «De manera genérica, se sitúa fuera del ámbito de protección de dicho derecho la difusión de las frases y expresiones ultrajantes u ofensivas, sin relación con las ideas u opiniones que se quieran exponer, y por tanto, innecesarias a este propósito (SSTC 204/1997, de 25 de noviembre; 11/2000, de 17 de enero, FJ 7; 49/2001, de 26 de febrero, FJ 5; 160/2003, de 15 de septiembre, FJ 4)» (STC 235/2007, FJ 5)

19 Remite el FJ 5 de la STC 235/2007 al FJ 8 de la STC 214/1991 según el cual «[...], ni la libertad ideológica (artículo 16 CE) ni la libertad de expresión (artículo 20.1 CE) comprenden el derecho a efectuar manifestaciones, expresiones o campañas de carácter racista o xenófobo, puesto que, tal como dispone el artículo 20.4, no existen derechos ilimitados y ello es contrario no sólo al derecho al honor de la persona o personas directamente afectadas, sino a otros bienes constitucionales como el de la dignidad humana (artículo $10 \mathrm{CE}$ ), que han de respetar tanto los poderes públicos como los propios ciudadanos, de acuerdo con lo dispuesto en los artículos 9 y 10 de la Constitución. La dignidad como rango o categoría de la persona como tal, del que deriva y en el que se proyecta el derecho al honor (art. 18.1 C.E.), no admite discriminación alguna por razón de nacimiento, raza o sexo, opiniones o creencias. El odio y el desprecio a todo un pueblo o a una etnia (a cualquier pueblo o a cualquier etnia) son incompatibles con el respeto a la dignidad humana, que sólo se cumple si se atribuye por igual a todo hombre, a toda etnia, a todos los pueblos» (FJ 8). 
de menospreciar y discriminar a personas o grupos por razón de cualquier condición o circunstancia personal, étnica o social el que, en estos casos, priva de protección constitucional a la expresión y difusión de un determinado entendimiento de la historia o concepción del mundo que, de no ser por ello, podría encuadrarse en el ámbito constitucionalmente garantizado por el art. 20.1 CE» (FJ 5).

A juicio de nuestra jurisdicción constitucional, los anteriores límites vienen a coincidir esencialmente con los declarados por el TEDH al aplicar los límites del art. 10 de la Convención para excluir de la protección dispensada a la libertad de expresión al «discurso del odio, esto es, a aquél desarrollado en términos que supongan una incitación directa a la violencia contra los ciudadanos en general o contra determinadas razas o creencias en particular», remitiéndose al respecto a las SSTEDH Ergogdu \& Ince c. Turquía de 8 de julio de 1999, Gündüz c. Turquía de 4 de diciembre de 2003, $\$ 41 ;$ y Erbakan c. Turquía de 6 de julio de 2006. Los términos de "discurso de odio", en virtud del Anexo de la Recomendación núm. R (97) 20 del Comité de Ministros del Consejo de Europa de 30 de octubre de 1997, «deben ser entendidos como abarcando todas las formas de expresión que propaguen, inciten, promuevan o justifiquen el odio racial, la xenofobia, el antisemitismo u otras formas de odio basadas en la intolerancia (...)» y el TEDH ha declarado al respecto que, «a la vista de los instrumentos internacionales ${ }^{20}[. .$.$] y de su propia jurisprudencia [...] la tolerancia y el respeto de$ la igual dignidad de todos los seres humanos constituyen el fundamento de una sociedad democrática y pluralista. De ello resulta que en principio se puede juzgar necesario, en las sociedades democráticas, sancionar o prevenir todas las for-

${ }^{20}$ Como instrumentos internacionales que contienen disposiciones que prohíben los discursos de odio, todas las formas de intolerancia y de discriminación fundada en la raza, la religión, las convicciones, etc. enumera el TEDH la Carta de las Naciones Unidas de 1945 [apartado 2 del Preámbulo, ars. 1.3, 13.1.b), 55.c) y 76.c)], la Declaración Universal de los Derechos Humanos de 1948 (arts. 1, 2 y 7), el Pacto Internacional sobre Derechos Civiles y Políticos de 1966 (arts. 2.1, 20.2 y 20.26), el Convenio Internacional de 1965 sobre la Eliminación de Todas las Formas de Discriminación Racial (arts. 4 y 5), la Declaración de 1981 sobre Todas las Formas de Intolerancia y de Discriminación basadas en la Religión o las Convicciones, la Declaración de Viena, adoptada el 9 de octubre de 1993, la Resolución núm. 52/122 sobre la eliminación de todas las formas de intolerancia religiosa adoptada por la Asamblea General de las Naciones Unidas el 12 de diciembre de 1997 y, particularmente, la Recomendación núm. R (97) 20 aprobada el 30 de octubre de 1997 por el Comité de Ministros del Consejo de Europa y la Recomendación del 13 de diciembre de 2002 de política general núm. 7 de la Comisión europea contra el racismo y la intolerancia (ECRI) sobre la legislación nacional para luchar contra el racismo y la discriminación racial (STEDH Güzdük, $\$ \$ 21-24)$. 
mas de expresión que propaguen, inciten, promuevan o justifiquen un odio basado en la intolerancia (incluida la intolerancia religiosa), si se quiere que las «formalidades», «condiciones», «restricciones» o «sanciones» impuestas sean proporcionadas al fin legítimo perseguido (en lo que respecta al discurso de odio y a la apología de la violencia, véase, mutatis mutandis, Sürek c. Turquía, $\$$ 62.) [...] Además, nadie duda de que expresiones concretas que constituyen un discurso de odio, como el Tribunal ha señalado en el asunto Jersild c. Dinamarca $(\$ 35)$, y que pueden ser insultantes para personas o grupos, no se benefician de la protección del artículo 10 del Convenio ${ }^{21}$ » (SSTEDH Gündüz, $\$ \$ 40$ y 41; y Erbakan, $\$ \$ 56$ y 57).

Además de esos límites, el Tribunal Constitucional invoca la posibilidad de que, en virtud de la cláusula de abuso del derecho del art. $17 \mathrm{CEDH}$, las doctrinas racistas y revisionistas pueden verse sustraídas a la protección que a la libertad de expresión otorga el art. 10 de la Convención de Roma, sin perjuicio de que afirme que dicha cláusula «no tiene parangón en nuestro ordenamiento constitucional» (FJ 5). Se remite así nuestro máximo interprete constitucional a la jurisprudencia del TEDH sobre el racismo y el revisionismo histórico que merece alguna consideración más detallada en su conjunto y no sólo en los párrafos transcritos en la STC 235/2007.

La primera sentencia de la Corte de Estrasburgo sobre esta temática fue la STEDH Jersild c. Dinamarca, de 23 de septiembre de 1994 en la que el Tribunal consideró que la condena penal de un periodista por entrevistar a miembros de un grupo juvenil racista y emitir por televisión sus declaraciones ofensivas para los inmigrantes vulneraba la libertad de expresión del art. $10 \mathrm{CEDH}$. En este caso, el demandante no era el autor de las declaraciones pero había sido condenado por complicidad por considerar los tribunales daneses que conocía el riesgo de que se produjeran las declaraciones racistas e incluso habría animado la expresión del discurso xenófobo sin ninguna réplica durante la emisión del programa. Aunque la sentencia se centró en gran parte en el papel de la prensa en una sociedad democrática, se pronunció también, no obstante, sobre los discursos de corte racista y xenófobo para declararlos excluidos de la protección del art. 10 de la Convención, aunque sin aplicar el art. 17 CEDH y ello sobre la

${ }^{21}$ Obsérvese, pues, que aunque la doctrina sobre el «discurso del odio» ha sido elaborada por el TEDH en el contexto de los casos relacionados con el conflicto del independentismo kurdo y Turquía a partir de la Sentencia Sürek contra Turquía, de 8 de julio de 1999, los insultos racistas y xenófobos a los que se refiere la Sentencia Jersild c. Dinamarca, de 23 de septiembre de 1994 han sido considerados a posteriori incluidos en dicho discurso y, en cuanto tales, excluidos de la protección del art. $10 \mathrm{CEDH}$. 
base de considerar que, en su conjunto, el reportaje no podía considerarse favorable a la propagación de ideas y opiniones racistas que califica de «antimorales, peligrosas e ilegales»: «sancionar a un periodista por haber coadyuvado a la difusión de declaraciones emanadas de un tercero en una entrevista, obstaculizaría gravemente la contribución de la prensa a las discusiones sobre problemas de interés general, que sólo podrían concebirse por razones particularmente serias. [....] Nadie pone en entredicho que las observaciones que han originado la condena de los camisas verdes eran más que insultantes para los miembros de los grupos afectados y en modo alguno podían acogerse a la protección del ar-

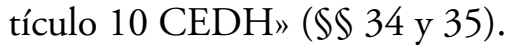

En el mismo sentido se pronunció en la Sentencia Ibrahim Aksoy c. Turquía, de 10 de octubre de 2000, que, en el contexto de la condena por propaganda separatista de un dirigente político turco de origen kurdo que se pretendía justificar en que sus declaraciones incitaban al odio y a la discriminación racial, ha señalado, remitiéndose a la Sentencia Jersild que «el Tribunal [...] se muestra particularmente vigilante sobre la propagación de ideas y opiniones racistas [...]. No hay duda de que los propósitos de incitar a la sociedad al odio racial y a propagar la idea de una raza superior no pueden beneficiarse de la protección del artículo 10 de la Convención [...].» (\$ 63).

Posteriormente, en la Sentencia Lehideux e Isorni c. Francia, de 23 de septiembre de 1998, el TEDH declaró también, aunque obiter dicta, que las tesis negacionistas o revisionistas del Holocausto de los judíos durante la Segunda Guerra Mundial quedan excluidas de la protección del art. 10 de la Convención por considerar que, en aplicación del art. 17 de la misma, el art. 10 no puede interpretarse en el sentido de implicar un derecho a realizar actividades o actos tendentes a la destrucción de los derechos y libertades garantizados por el CEDH. A diferencia del Tribunal Constitucional español que, como se ha visto anteriormente, reconoce en abstracto la legitimidad constitucional del debate histórico sobre el Holocausto - salvo que el pretendido discurso historicista sirva de mera pantalla para la ofensa o la incitación racista o antisemita al odio racial, a la violencia o a la discriminación-, la Corte Europea declaró excluido de raíz el «revisionismo histórico» de la protección de la Convención. Así, comparando el Holocausto con la controversia entre los historiadores acerca de la política del mariscal Pétain respecto a la Alemania nazi, se afirma en la meritada sentencia: «el Tribunal estima que no le corresponde arbitrar en esta cuestión, que pertenece a un debate todavía en curso entre los historiadores sobre el desarrollo y la interpretación de los acontecimientos de que se trata. Como tal, la cuestión escapa a la categoría de los hechos históricos claramente establecidos — como es el caso del Holocausto-, cuya negación o revisión se vería sustraída por el artículo 
17 a la protección del artículo 10 del Convenio ${ }^{22}$. En este caso, no parece que los recurrentes hayan querido negar o revisar lo que ellos mismos han llamado en su publicación las «atrocidades y persecuciones nazis» o la «omnipotencia alemana y su barbarie». Calificando de "supremamente hábil» la política de Philippe Pétain, los autores del texto han sostenido ante todo una de las tesis en presencia en el debate sobre el papel del jefe de gobierno de Vichy, la llamada tesis del «doble juego». [...] No cabe ninguna duda que, al igual que cualquier otro propósito dirigido contra los valores que subyacen al Convenio (ver mutatis mutandis, la Sentencia Jersild contra Dinamarca [...], \$35), la justificación de una política pro-nazi no podría beneficiarse de la protección del artículo $10 »$ ( $\$ \$ 47$ y 53).

En la Decisión de inadmisibilidad Garaudy c. Francia, de 24 de junio de 2003 , el TEDH ha reiterado su doctrina anterior $(\$ 1)$ y, al contrario que en la Sentencia Lehideux e Isorni, ha considerado que la finalidad última del libro publicado por el demandante era la rehabilitación del régimen nacional-socialista y la negación del Holocausto con objetivos racistas, lo que le impide gozar de la protección del art. $10 \mathrm{CEDH}$ en aplicación del art. 17 de la Convención. En palabras del Tribunal, «no puede haber duda de que la negación de la realidad de hechos históricos claramente establecidos, como el Holocausto, en la forma que lo hace el demandante en su libro, de ninguna manera tiene que ver con la investigación en búsqueda de la verdad. La finalidad y el resultado de este enfoque son completamente diferentes, el propósito verdadero es rehabilitar el régimen nacional-socialista y, como consecuencia, acusar a las propias victimas de falsificar la historia. Negar los crímenes contra la humanidad es, por lo tanto, una de las formas más graves de difamación racial a los judíos y de incitación al odio contra ellos [...]. El Tribunal considera que el contenido principal y el tenor

${ }^{22}$ En el caso resuelto por la sentencia el Tribunal de Apelación y el Gobierno francés argumentaban la existencia de una apología — «implícitamente pero necesariamente»— de la colaboración de Vichy con la Alemania nazi, instrumentada mediante el elogio de la política de Pétain con omisión de toda referencia a la legislación racial (ley de 3 de octubre de 1940 sobre los nacionales y extranjeros de raza judía que debían ser internados en campos establecidos en Francia al efecto para facilitar su traslado hacia los campos de concentración nazis a los que estaban destinados), equiparando tal apología al negacionismo del Holocausto en cuanto a la aplicabilidad del arts. $17 \mathrm{CEDH}$ por infringir el espíritu y los valores esenciales de la democracia, aplicabilidad que resultó negada tanto por la Comisión — «[...] el anuncio que había dado lugar a la condena de los recurrentes no contenía ninguna expresión de odio racial u otras afirmaciones dirigidas a destruir o restringir los derechos y libertades garantizados por la Convención» sino que su objeto era revisar la sentencia condenatoria de Pétain y no puede deducirse del texto que la expresión de las ideas de los recurrentes constituyera una «actividad» en el sentido del artículo 17 (\$37)— como por el TEDH. 
general del libro del demandante, y por ello su finalidad, son notoriamente revisionistas y, por lo tanto, son contrarios a los valores fundamentales de la Convención, tal y como están expresados en su Preámbulo, a saber, la justicia y la paz. Considera que el demandante intenta desviar el artículo 10 de la Convención de su verdadero propósito usando su derecho a la libertad de expresion para fines que son contrarios al texto y al espíritu de la Convención. Tales fines, si fueran admitidos, contribuirían a la destrucción de los derechos y libertades garantizados por la Convención. En consecuencia, el Tribunal considera que, de acuerdo con el artículo 17 de la Convención, el demandante no puede acogerse a las previsiones del artículo 10 con respecto a su opinión negacionista de crímenes contra la humanidad» $(\$ 1, \mathrm{i})$

Por su parte, la Sentencia Chauvy y otros c. Francia, de 23 de junio de 2004 ha venido a reiterar que el Holocausto pertenece «a la categoría de hechos históricos claramente establecidos [...] cuya negación o revisión pasaría de la protección del artículo 10 a la del artículo 17», a diferencia de otros episodios históricos también relacionados con la Segunda Guerra Mundial respecto de los que «el Tribunal considera que la búsqueda de la verdad histórica forma parte integrante de la libertad de expresión y encuentra que no le compete arbitrar la cuestión histórica de fondo, que pertenece al ámbito de un debate siempre en curso entre historiadores y en el seno mismo de la opinión sobre el desarrollo y la interpretación de los acontecimientos de los que se trata» (\$69), en este último sentido, también en la Sentencia Monnat contra Suiza, de 21 de septiembre de 2006 (\$ 57).

Pero este posible recurso a la invocación del art. $17 \mathrm{CEDH}$ para excepcionar la aplicación de las garantías de los derechos de la Convención y, en particular, del ámbito de protección establecido en el art. 10 para la libertad de expresión, exige, para el Tribunal Constitucional español, no sólo la constatación de un daño «sino que es preciso corroborar además la voluntad expresa, de quienes pretenden ampararse en la libertad de expresión, de destruir con su ejercicio las libertades y el pluralismo o de atentar contra las libertades reconocidas en el Convenio (STEDH Refah partisi y otros c. Turquía, de 13 febrero 2003, $\$ 98$; Decisión Fdanoka c. Letonia, de 17 junio $2004, \$ 79)$. Sólo en tales casos, a juicio del Tribunal Europeo, los Estados podrían, dentro de su margen de apreciación, permitir en su derecho interno la restricción de la libertad de expresión de quienes niegan hechos históricos claramente establecidos, con el buen entendimiento de que el Convenio tan sólo establece un mínimo común europeo que no puede ser interpretado en el sentido de limitar las libertades fundamentales reconocidas por los ordenamientos constitucionales internos (art. 53 $\mathrm{CEDH}) »(\mathrm{STC} 235 / 2007, \mathrm{FJ} 5)$. 


\section{CONCLUSIONES DE LA STC 235/2007}

\section{La incidencia de los tipos penales del art. 607.2 del Código Penal en la libertad de expresión}

Desde los anteriores presupuestos, el Tribunal aborda en el FJ 6 el análisis de la constitucionalidad del precepto impugnado, el primer inciso del art. 607.2 CP, y parte para ello de su ubicación sistemática dentro de un conjunto de tipos penales con los que está temáticamente relacionado y mediante los cuales se ha dado cumplimiento a las obligaciones internacionales adquiridas por España en materia de persecución y prevención del genocidio en virtud de la ratificación de tratados internacionales, citando en particular el art. 20.2 del Pacto Internacional de Derechos Civiles y Políticos de 19 de diciembre de 1966 — «toda apología del odio nacional, racial o religioso que constituya incitación a la discriminación, la hostilidad o la violencia estará prohibida por la ley»- y el art. V del Convenio de Naciones Unidas para la Prevención y la Sanción del Delito de Genocidio, de 9 de diciembre de 1948, en virtud del cual España, como parte contratante. se comprometió, a establecer, con arreglo a su Constitución, «sanciones penales eficaces para castigar a las personas culpables de genocidio» o de «instigación directa y pública» a cometerlo» [art. III c)].

En ese contexto sistemático de delitos conexos con el art. 607, como son los arts. $510,515.5 .^{\circ}$ (que tipifica como asociaciones ilícitas «las que promuevan la discriminación, el odio o la violencia contra personas, grupos o asociaciones por razón de su ideología, religión o creencias, la pertenencia de sus miembros o de alguno de ellos a una etnia, raza o nación, su sexo, orientación sexual, situación familiar, enfermedad o minusvalía, o inciten a ello»), 519 (que penaliza la provocación, la conspiración y la proposición para cometer el delito de asociación ilícita) y 615 del Código Penal, el juez constitucional se detiene especialmente «dada la cercanía de las conductas perseguidas», en los arts. 615 y 510.1, relativos respectivamente a la provocación, la conspiración y la proposición para la ejecución de los delitos contra la comunidad internacional (entre ellos, el delito de genocidio del art. 607) y al delito de provocación a la discriminación, al odio o a la violencia contra grupos o asociaciones, por motivos racistas, antisemitas u otros referentes a la ideología, religión o creencias, situación familiar, la pertenencia de sus miembros a una etnia o raza, su origen nacional, su sexo, orientación sexual, enfermedad o minusvalía ${ }^{23}$ - delito que, a decir del Tribunal, fue

${ }^{23}$ Con relación a este delito, P. Laurenzo Copello, sin perjuicio de señalar el carácter positivo del punto de partida de la reforma del Código Penal, se muestra especialmente crítica en lo que 
«introducido en el Código Penal de 1995 como consecuencia directa de la doctrina sentada [...] en la STC 214/1991»—, señalando además que «los títulos dedicados a los delitos contra el honor y los relativos al ejercicio de los derechos fundamentales y las libertades públicas vienen a completar el ámbito penal de protección en el que se inserta también el precepto cuestionado».

Contextualizado así el art. 607, el Alto Tribunal pasa a contraponer el primer apartado de dicho artículo, que «cierra el sistema específico de protección exigido por los instrumentos internacionales en la materia que vinculan a nuestro Estado, castigando las diversas modalidades de comisión de este delito», con el apartado segundo cuestionado de inconstitucionalidad para destacar una diferencia fundamental: mientras que el art. 607.1 exige «un dolo específico» —el "propósito de destruir total o parcialmente a un grupo nacional, étnico, racial o religioso»-, el art. 607.2 se configura como «un tipo penal independiente en el que ya no se incluye dicho dolo específico ${ }^{24}$ y que castiga la difusión de determinadas ideas o doctrinas».

Con esta distinción el Tribunal viene a asumir el razonamiento de la Audiencia Provincial en el auto de planteamiento de la cuestión; argumentaba el órgano cuestionante que el art. 607.2 CP es un tipo penal autónomo en el que la

se refiere a la tipificación de la provocación al odio por constituir «una limitación inaceptable del derecho fundamental a expresar libremente las ideas [...] Una interpretación literal del término llevaría a incluir aquí cualquier apelación a los sentimientos que contenga una carga de menosprecio hacia alguno de los grupos protegidos. Así [...] bastaría cualquier escrito que, en términos despectivos, atribuyera el problema del paro en España a la presencia de inmigrantes ilegales, para que estuviéramos ya ante una conducta idónea para despertar sentimientos de rechazo hacia ese colectivo y, por tanto, típica del artículo 510» (ob. cit., págs. 227 y 258-260). En el mismo sentido se manifiesta J. M. Tamarit Sumalla para quién se trata de un delito de naturaleza sui generis "[...] en el que se llega a castigar la provocación de una emoción humana, el odio, algo que lógicamente en cualquier caso no resulta constitutivo de delito» (ob. cit., pág. 1436).

${ }^{24}$ Contrariamente a lo afirmado por la sentencia, el voto particular (VP en adelante) del magistrado P. Sala Sánchez argumenta que el dolo específico del delito de genocidio es extensible al art. 607.2; así, afirma que «el artículo 607. 2 CP [...] define el delito de genocidio con un presupuesto común a todas las modalidades comisivas que contempla, a saber: la exigencia del propósito de destruir total o parcialmente a un grupo nacional, étnico, racial o religioso. Lo que ocurre es que el artículo 607.1, en sus cinco ordinales, hace referencia a conductas directa y hasta físicamente lesivas de bienes jurídicos ligados a la vida, integridad física, salud o condiciones de vida y, en cambio, el artículo 607.2 CP hace relación solamente, como se ha repetido, a la difusión de ideas o doctrinas que nieguen o justifiquen no los hechos sustentadores de las formas comisivas del ap.1, sino «los delitos tipificados» en dicho apartado, delitos estos que no pueden cometerse sin el "propósito» previo anteriormente destacado. Al ser así, entender que ese elemento tendencial está también inmerso en las modalidades comisivas del tan mencionado ap. 2 es un razonamiento perfectamente coherente con la más elemental lógica jurídica». 
conducta descrita no es integrable en la definición genérica de la apología realizada en el art. $18 \mathrm{CP}$ ni tampoco coincide con las conductas tipificadas en ninguno de los preceptos penales conexos (arts. 510, 515.5. $.^{\circ}, 519$ y $615 \mathrm{CP}$ ) y ello por cuanto «la conducta sancionada por el art. $607.2 \mathrm{CP}$ es [...] exclusivamente la de difundir ideas o doctrinas que nieguen o justifiquen los delitos de genocidio $^{25}$, conducta que coincide con la que dio lugar a la condena en instancia del Sr. Varela Geiss por tener una librería especializada en la venta de determinados libros y demás medios de difusión de ideas e información relativos a la negación y justificación del genocidio judío por el régimen nacionalsocialista durante la Segunda Guerra Mundial» (Antecedente 3).

Efectivamente, la sentencia afirma que «la literalidad del ilícito previsto en el art. 607.2 CP no exige, a primera vista, acciones positivas de proselitismo xenófobo o racista, ni menos aún la incitación, siquiera indirecta, a cometer genocidio, que sí están presentes, por lo que hace al odio racial o antisemita se refiere, en el delito previsto en el art. $510 \mathrm{CP}$, castigado con penas superiores. Las conductas descritas tampoco implican necesariamente el ensalzamiento de los genocidas ni la intención de descrédito, menosprecio o humillación de las víctimas ${ }^{26}$ »; no hay, por tanto, ni apología que pueda ser punible como forma de provocación (en la medida que no hay ensalzamiento del crimen ni enalteci-

${ }^{25}$ A este respecto J. M. Tamarit Sumilla califica el art. 607.2 CP como «una suerte de delito de opinión [...] Con este nuevo delito lo que se castiga es la mera difusión de ideas o doctrinas, lo cual no es sino la criminalización de una ideología, lo cual, por muy nefasta que la misma resulte, no constituye una actitud propia de un Estado democrático». ["Artículo 607» en G. QUINTERO Olivares (dir.), y otros, Comentarios a la Parte Especial del Derecho Penal, Aranzadi, Madrid, 1996, págs. 1641 y 1642]

${ }^{26}$ Discrepa de esta afirmación el VP del magistrado R. Rodríguez Arribas para quien «el llamado "negacionismo" es, en si mismo y cuando menos, un claro menosprecio hacia las víctimas que lo sufrieron y así se presenta en cuantas ocasiones se produce en la realidad de quienes sostienen, por ejemplo, que el holocausto no existió y que solo es propaganda sionista; pretender amparar semejantes actitudes en la libertad de expresión es degradarla; por el contrario, y como sostiene el Ministerio Fiscal, dichas actitudes van encaminadas a hacer surgir estados de opinión tergiversados sobre este hecho histórico, ciertamente contrarios a lo que realmente aconteció, tratando así de fomentar el olvido del mismo, por lo que el precepto no trata de castigar la libre difusión de ideas u opiniones, por muy reprobables y rechazables moralmente que fueran, sino de proteger a la sociedad de aquellos comportamientos que una sistemática preparación sicológica de la población, a través de medios propagandísticos, generaría un clima de violencia y hostilidad que, de forma mediata, pudiera concretarse en actos específicos de discriminación racial, étnica o religiosa; ciertamente éste es un peligro que una sociedad democrática no puede permitirse correr en las actuales circunstancias, en las que no puede negarse el rebrote de esas actitudes» (apartado 1 ). 
miento de su autor que por su naturaleza y circunstancias pudieran considerarse como una incitación directa constitutiva de provocación para el delito de genocidio, en virtud de los arts. 18 y $615 \mathrm{CP}^{27}$ ) ni tampoco incitación indirecta punible a través del art. $510 \mathrm{CP}$.

Así pues, para el Tribunal no hay duda de que el art. 607.2 CP afecta a la libertad de expresión del art. 20.1 CE en la medida que la conducta tipificada no incorpora la concurrencia de una intención o propósito cualificado o adicional: «la incidencia de este tipo punitivo previsto en el art. 607.2 CP sobre el derecho fundamental a la libertad de expresión (art. 20.1 CE) viene determinada por la inicial descripción de las conductas perseguidas, consistentes en difundir por cualquier medio ideas o doctrinas ya que, puesto que no se exige expresamente elemento suplementario alguno, hay que considerar que en principio se trata de una difusión en cierto modo «neutra», con independencia de la repulsión que determinadas afirmaciones puedan causar».

Pero, para el juez constitucional, no sólo hay afectación o incidencia sobre la libertad de expresión sino invasión de su contenido constitucional por el legislador penal, anticipando ya su posterior juicio de inconstitucionalidad parcial; en la medida que lo que se penaliza no es aquella difusión de ideas o doctrinas cualificada por una determinada intencionalidad ofensiva o vilipendiadora, sino la pura y desnuda transmisión de ideas, pensamientos y opiniones, no se está estableciendo un límite externo a la libertad de expresión en ciertas circunstancias sino que el legislador penetra en el contenido esencial del derecho para delimitarlo internamente ${ }^{28}$.

27 Dispone el art. 18 CP:

«1. La provocación existe cuando directamente se incita por medio de la imprenta, la radiodifusión o cualquier otro medio de eficacia semejante, que facilite la publicidad, o ante una concurrencia de personas, a la perpetración de un delito.

Es apología, a los efectos de este Código, la exposición, ante una concurrencia de personas o por cualquier medio de difusión, de ideas o doctrinas que ensalcen el crimen o enaltezcan a su autor. La apología sólo será delictiva como forma de provocación y si por su naturaleza y circunstancias constituye una incitación directa a cometer un delito.

2. La provocación se castigará exclusivamente en los casos en que la Ley así lo prevea.

Si a la provocación hubiese seguido la perpetración del delito, se castigará como inducción».

Por su parte, según el art. 615, «la provocación, la conspiración y la proposición para la ejecución de los delitos previstos en este Título [Título XXIV. Delitos contra la comunidad internacional, arts. 605-616], se castigarán con la pena inferior en uno o dos grados a la que correspondería a los mismos».

${ }^{28}$ En palabras de la STC 235/2007, «la literalidad del precepto, en la medida en que castiga la transmisión de ideas en sí misma considerada, sin exigir adicionalmente la lesión de otros bienes 


\section{La inanidad de la mera negación del genocidio}

Planteada la cuestión en estos términos, se ocupa en primer lugar el Tribunal de una de las dos conductas en las que cabe escindir el primer inciso del art. 607.2 CP «según que las ideas o doctrinas difundidas nieguen el genocidio o lo justifiquen», esto es, de la "mera negación de un delito de genocidio» que "a simple vista [...] puede ser entendida como mera expresión de un punto de vista sobre determinados hechos, sosteniendo que no sucedieron o no se realizaron de modo que puedan ser calificados de genocidio» (FJ 7) para valorar si, confrontada dicha conducta negadora con el «discurso del odio» — tal y como se ha expuesto que lo ha caracterizado el TEDH en términos de «incitación directa a la violencia contra los ciudadanos o contra determinadas razas o creencias»-, puede calificarse como una «modalidad» del mismo que no gozaría de la cobertura proporcionada por la libertad de expresión.

Maneja el Alto Tribunal varios argumentos al respecto para llegar a una conclusión negativa:

1. La punición de la negación del genocidio afectaría, no sólo al ámbito de la libertad de expresión sino también a aquellas otras libertades "que se manifiestan a su través» (FJ 6) como la libertad ideológica del art. 16 CE y, especialmente, la libertad científica en el ámbito de la investigación histórica; así, afirma que «la mera difusión de conclusiones en torno a la existencia o no de determinados hechos, sin emitir juicios de valor sobre los mismos o su antijuridicidad, afecta al ámbito de la libertad científica ${ }^{29}$ reconocida en la letra b) del art. 20.1

constitucionalmente protegidos, viene aparentemente a perseguir una conducta que, en cuanto amparada por el derecho a la libertad de expresión (art. 20.1 CE) e incluso eventualmente por la libertades científica [art. 20.1. b)] y de conciencia (art. 16 CE) que se manifiestan a su través (STC 20/1990, FJ 5), constituye un límite infranqueable para el legislador penal. En tal sentido, no estamos ante un supuesto de limitación de la libertad de expresión por parte del Código Penal, sino que éste interfiere en el ámbito propio de la delimitación misma del derecho constitucional. Más allá del riesgo, indeseable en el Estado democrático, de hacer del Derecho penal un factor de disuasión del ejercicio de la libertad de expresión, del que hemos advertido en otras ocasiones (SSTC 105/1990, FFJ 4 y 8; 287/2000, de 11 de diciembre, FJ 4; STEDH, caso Castells, 23 de abril de 1992, $\$ 46$ ), a las normas penales les está vedado invadir el contenido constitucionalmente garantizado de los derechos fundamentales. La libertad de configuración del legislador penal encuentra su límite en el contenido esencial del derecho a la libertad de expresión, de tal modo que, por lo que ahora interesa, nuestro ordenamiento constitucional no permite la tipificación como delito de la mera transmisión de ideas, ni siquiera en los casos en que se trate de ideas execrables por resultar contrarias a la dignidad humana que constituye el fundamento de todos los derechos que recoge la Constitución y, por ende, de nuestro sistema político» (FJ 6).

29 En sentido contrario el VP de Rodríguez Arribas, que, sobre la base de que el delito de difusión de ideas negacionistas participa del mismo elemento intencional que la justificación del ge- 
CE» (FJ 8). Se remite así el Tribunal al FJ 4 de la STC 43/2004, de 23 de marzo, en la que ha declarado la protección acrecida de que la libertad científica goza en la Constitución respecto a las de expresión e información, justificando esta mayor amplitud de su ámbito de protección constitucional en que «sólo de esta manera se hace posible la investigación histórica, que es siempre, por definición, polémica y discutible, por erigirse alrededor de aseveraciones y juicios de valor sobre cuya verdad objetiva es imposible alcanzar plena certidumbre, siendo así que esa incertidumbre consustancial al debate histórico representa lo que éste tiene de más valioso, respetable y digno de protección por el papel esencial que desempeña en la formación de una conciencia histórica adecuada a la dignidad de los ciudadanos de una sociedad libre y democrática».

2. La constitucionalidad del precepto sólo sería defendible si se le añadiera hermenéuticamente un elemento de intencionalidad tendencial no presente en su tenor literal, a saber, que «toda negación de conductas jurídicamente calificadas como delito de genocidio persigue objetivamente la creación de un clima social de hostilidad contra aquellas personas que pertenezcan a los mismos grupos que en su día fueron víctimas del concreto delito de genocidio cuya inexistencia se pretende» o bien que «toda negación sea per se capaz de conseguirlo»; pero el Tribunal considera que, en primer lugar, desde la perspectiva del juicio de proporcionalidad que debe superar toda injerencia restrictiva en un derecho fundamental, «una finalidad meramente preventiva o de aseguramiento no puede justificar constitucionalmente una restricción tan radical de estas libertades (STC 199/1987, de 16 de diciembre, FJ 12)» y, en segundo lugar, que, en todo caso «la constitucionalidad, a priori, del precepto se estaría sustentando en la exigencia de otro elemento adicional no expreso del delito del art. 607.2 CP; a saber, que la conducta sancionada consistente en difundir opiniones que nieguen el genocidio fuese en verdad idónea para crear una actitud de hostilidad hacia el colectivo afectado». Ello es inaceptable porque supondría forzar la interpretación del art. 607.2 CP «añadiéndole nuevos elementos» lo que «desbordaría los límites de esta jurisdicción al imponer una interpretación del precepto por completo contraria a su tenor literal»; la improcedencia de tal interpretación im-

nocidio, rechaza que el art. 607.2 CP «pueda ser vulnerador de la libertad científica (art.. 20.1.b) CE) porque no se trata de castigar el resultado de la investigación de un historiador demenciado que llegara a la absurda conclusión de la inexistencia de un genocidio universalmente contrastado, en cuyo caso no habría elemento intencional alguno, y por lo tanto no resultaría punible, sino de poner coto, mediante la sanción penal, a la profusión de informaciones directamente encaminadas a minimizar o a explicar hechos monstruosos de genocidio para romper la barrera de repugnancia social que impide su temible repetición» (apartado 2). 
plica que, de aplicarse la literalidad del precepto, se estaría sancionando una conducta que "permanece en un estadio previo al que justifica la intervención del derecho penal, en cuanto no constituye, siquiera, un peligro potencial para los bienes jurídicos tutelados por la norma en cuestión, de modo que su inclusión en el precepto supone la vulneración del derecho a la libertad de expresión (art. 20.1 CE)».

En virtud de lo expuesto, concluye el juez constitucional que, no pudiendo reconducirse la conducta negadora al «discurso del odio» ni siendo admisible una interpretación contra legem del art. 607.2 que exija para la punición de la conducta típica la presencia de un ánimo o de un resultado favorecedor de un clima social de hostilidad ${ }^{30}$, «la mera negación del delito, frente a otras conductas que comportan determinada adhesión valorativa al hecho criminal, promocionándolo a través de la exteriorización de un juicio positivo, resulta en principio inane» (FJ 8).

\section{La constitucionalidad de la sanción penal de la justificación del genocidio: una sentencia interpretativa}

«Diferente es la conclusión a propósito de la conducta consistente en difundir ideas que justifiquen el genocidio». Con estas palabras inicia el Alto Tribunal el FJ 9 en el que valora la constitucionalidad de la segunda de las conductas a las que se refiere el primer inciso del art. 607.2 CP, la justificación de los delitos de genocidio que, a juicio del TC «no implica la negación absoluta de la existencia de determinado delito de genocidio sino su relativización o la negación de su antijuricidad partiendo de cierta identificación con los autores» (FJ 7).

La justificación del delito de genocidio supone, según el Tribunal, «la expresión de un juicio de valor» y en esa medida «resulta posible apreciar el citado elemento tendencial en la justificación pública del genocidio ${ }^{31} »$, es decir, en este

30 En este sentido, P. Laurenzo Copello propone una interpretación de este artículo conforme a la STC 176/1995 de tal manera que la negación del genocidio sólo sería punible cuando vaya acompañada de juicios peyorativos y humillantes hacia las víctimas que ataquen su dignidad (ob. cit., págs. 260-264).

31 Para el magistrado discrepante Sala Sánchez es contradictorio entender que el art. 607.2 $\mathrm{CP}$ exige un elemento tendencial al tipificar la difusión de ideas o doctrinas que justifiquen el genocidio y negar la presencia de ese mismo elemento tendencial en la penalización de la difusión de las que lo nieguen, "habida cuenta que la figura delictiva las identifica cuando coloca en la misma posición la negación y la justificación, conductas a las que simplemente separa por la disyuntiva "o"» (VP). En el mismo sentido se pronuncia in fine el VP de Rodríguez Arribas 
caso la conducta típica exige la presencia de un ánimo, finalidad u objetivo exculpatorio de las prácticas genocidas.

A partir de esta afirmación, el juez constitucional realiza una interpretación del art. 607.2 a la que luego remitirá el fallo en el que declara que «no es inconstitucional el primer inciso del art. 607.2 del Código Penal que castiga la difusión de ideas o doctrinas tendentes a justificar un delito de genocidio, interpretado en los términos del fundamento jurídico 9 de esta Sentencia». Dicta así el Tribunal una sentencia parcialmente interpretativa después de que en el FJ 7 haya afirmado su legitimidad para ello sobre la base del principio de conservación de la ley respetando los límites de la interpretación contra legem de las normas y de la reconstrucción de una norma no explicitada en el texto legal creando una norma nueva, como sería propio de un legislador positivo y no de la jurisdicción constitucional ${ }^{32}$.

$\mathrm{La}$ «interpretación conforme» del art. 607.2 CP, en la parte que reprocha penalmente la difusión de ideas o doctrinas que justifiquen el genocidio, vendrá determinada por una doble limitación que se impone a la libertad de configuración del legislador penal:

1. La justificación es punible «siempre que tal justificación opere como incitación indirecta a su comisión; esto es incriminándose (y ello es lo que ha de entenderse que realiza el art. 607.2 CP) conductas que aunque sea de forma indirecta supongan una provocación al genocidio», fundamentando la sanción penal en que «la especial peligrosidad de delitos tan odiosos [...] que ponen en riesgo la esencia misma de nuestra sociedad, como el genocidio, permite excepcionalmente que el legislador penal sin quebranto constitucional castigue la justificación pública de ese delito». Explicita el Tribunal que son dos los casos en los que la difusión pública de las ideas justificadoras entran en conflicto con

32 Estos límites de las sentencias interpretativas serían también respetados, a juicio de Sala Sánchez, si la misma interpretación que permite a la sentencia salvar la constitucionalidad de la sanción penal de las difusión pública de la justificación del genocidio, se realizase a propósito de la negación por cuanto la exigencia en la conducta de difusión de doctrinas que nieguen los delitos de genocidio del elemento tendencial de incitación indirecta a la violencia o al odio no puede ser calificada de desfiguración o manipulación del texto legal, "cuando es lo cierto que ese elemento tampoco figura explicitado en la conducta equivalente de justificación y cuando no sería nunca admisible interpretar que el legislador del Código Penal hubiera querido incriminar solo una aséptica conducta de negación fáctica desprovista de toda intencionalidad. Ésta, con todos los respetos, sí podría merecer el concepto de interpretación abusiva y sacada de contexto y, al propio tiempo, el de una innecesaria restricción en la incriminación de conductas penalizadoras del gráficamente llamado «discurso del odio», que todas las modalidades de genocidio y de su defensa implican y que todo Estado democrático está obligado a perseguir»(VP). 
«bienes constitucionalmente relevantes de especial trascendencia» merecedores de la protección penal:

a) «Cuando la justificación de tan abominable delito suponga un modo de incitación indirecta a su perpetración», reiterando así el supuesto general sin mayores concreciones.

b) «Cuando con la conducta consistente en presentar como justo el delito de genocidio se busque alguna suerte de provocación al odio hacia determinados grupos definidos mediante la referencia a su color, raza, religión u origen nacional o étnico, de tal manera que represente un peligro cierto de generar un clima de violencia y hostilidad que puede concretarse en actos específicos de discriminación». En este segundo supuesto, la justificación persigue crear un ambiente propicio que facilite la realización, en un momento posterior, de la conducta tipificada en el art. 510.1 CP; vendría a ser una suerte de conducta preparatoria de la provocación a la discriminación, al odio o a la violencia ${ }^{33}$.

El bien jurídico protegido cuya relevancia constitucional permite la punición de la incitación indirecta al genocidio mediante la difusión de ideas o doctrinas justificadoras de tal crimen no es otro que la dignidad y los derechos fundamentales que de ella emanan: «la incitación indirecta a la comisión de algunas de las conductas tipificadas en el art. 607.1 CP como delito de genocidio - entre las que se incluyen entre otras el asesinato, las agresiones sexuales o los desplazamientos forzosos de población - cometidas con el propósito de exterminar a todo un grupo humano, afecta de manera especial a la esencia de la dignidad de la persona, en cuanto fundamento del orden político (art. $10 \mathrm{CE}$ ) y sustento de los derechos fundamentales. Tan íntima vinculación con el valor nuclear de cualquier sistema jurídico basado en el respeto a los derechos de la persona permite al legislador perseguir en este delito modalidades de provocación, incluso indirecta, que en otro caso podrían quedar fuera del ámbito del reproche penal».

2. El segundo límite que condiciona la constitucionalidad de la sanción penal a la justificación del genocidio es la libertad ideológica reconocida en el art. 16 CE sin más limitación que el mantenimiento del orden público protegido por la ley y que se encuentra reconocida por el constituyente con la «máxima

33 Según el VP de Sala Sánchez, esta interpretación de que la justificación equivale a incitación directa en los dos casos mencionados sería también perfectamente aplicable a la negación, argumentando que "lo que el precepto cuestionado castiga en las dos conductas — no se olvide, legislativamente equiparadas - no es la simple "negación» en abstracto o la «justificación» consistente en «la proclamación de ideas o posiciones políticas propias o adhesión a las ajenas» (FJ.9), sino esas mismas «negación» o «justificación» en cuanto signifiquen, como acaba de decirse, la presentación como justo de un delito de genocidio en términos tales que suponga una incitación indirecta a su comisión». 
amplitud» (STC 20/1990, FFJJ 3, 4 y 5); en consecuencia, la libertad ideológica debe quedar al resguardo de la penalización de la justificación pública del genocidio. Así lo afirma nuestro juez constitucional cuando dice que «el legislador puede, dentro de su libertad de configuración, perseguir tales conductas, incluso haciéndolas merecedoras de reproche penal siempre que no se entienda incluida en ellas la mera adhesión ideológica a posiciones políticas de cualquier tipo, que resultaría plenamente amparada por el art. $16 \mathrm{CE}$ y, en conexión, por el art. $20 \mathrm{CE}$; quedará, pues, vedada la condena por este delito cuando la imputación de la justificación del genocidio no venga dada por manifestaciones directamente imputables al sujeto sino por entender tal justificación implícita en las posiciones ideológicas profesadas.

Con estas reservas, la sentencia 235/2007 acepta la constitucionalidad de la justificación pública del genocidio entendiéndolo como «una manifestación del discurso del odio» cuya penalización se acomoda a los instrumentos internacionales, aduciéndose al efecto el art. 1 de la reciente Propuesta de Decisión Marco relativa a la lucha contra el racismo y la xenofobia, aprobada por el Consejo de la Unión Europea en reunión de 20 de abril de 2007 que, a diferencia del Convenio de Nueva York de 1948 ya no exige que la instigación al genocidio sea directa para su tipificación sino que obliga a los Estados miembros a adoptar medidas para garantizar que se castigue la apología pública, la negación o la trivialización flagrante de los crímenes de genocidio en los casos en los que «la conducta se ejecute de tal manera que pueda implicar una incitación a la violencia o al odio» contra el grupo social afectado, sin exigir por tanto el carácter directo de la incitación ${ }^{34}$.

La equiparación de las expresiones justificativas del genocidio con las manifestaciones insultantes que pueden llegar a incardinarse en la variante soft del «discurso del odio» a la que se refiere el TEDH cuando calificó como tales las ex-

${ }^{34}$ Esta misma Propuesta de Decisión Marco sirve de argumento al VP de Pascual Sala Sánchez para argumentar que el elemento tendencial cuya presencia fundamenta la constitucionalidad de la sanción penal de la justificación del genocidio para el parecer mayoritario del Tribunal, es extensible también a la penalización de la negación: «la Propuesta mencionada sigue en este punto el mismo criterio que el del artículo 607.2 del Código Penal español o, lo que es lo mismo, exige que tanto para la apología pública de los crímenes de terrorismo (en la Propuesta no se contempla directamente la justificación) como para su negación o trivialización es necesario el elemento tendencial de que «la conducta se ejecute de tal manera que pueda implicar una incitación a la violencia o al odio». Obsérvese cómo en este instrumento no se plantea duda alguna acerca de que la negación de los crímenes (calificación jurídica como es igualmente la de delitos que hace el Código español) entre en la obligación de los Estados de adoptar medidas punitivas o de castigo en su contra, siempre que, como en los demás casos (apología o trivialización), concurra el elemento tendencial de referencia». 
presiones insultantes vertidas en el supuesto juzgado en el caso Jersild c. Dinamarca es otro argumento adicional que ampara la constitucionalidad de su incriminación: «el comportamiento despectivo o degradante respecto a un grupo de personas no puede encontrar amparo en el ejercicio de las libertades garantizadas en el art. 20.1 CE, que no protegen «las expresiones absolutamente vejatorias, es decir, las que, en las concretas circunstancias del caso, y al margen de su veracidad o inveracidad, sean ofensivas u oprobiosas» (por todas SSTC 174/2006, de 5 de junio, FJ 4; 204/2001, de 15 de octubre, FJ 4; 110/2000, de 5 de mayo, FJ 8)».

Sobre estas bases entiende el Tribunal Constitucional que queda justificada la sanción penal de una conducta distinta a la incitación directa o a la provocación reiterando la necesidad de salvaguardar la libertad ideológica y que la protección de los derechos y libertades es la ratio fundamentadora de la opción del legislador penal: «de este modo resulta constitucionalmente legítimo castigar penalmente conductas que, aun cuando no resulten claramente idóneas para incitar directamente a la comisión de delitos contra el derecho de gentes como el genocidio, sí suponen una incitación indirecta a la misma o provocan de modo mediato a la discriminación, al odio o a la violencia, que es precisamente lo que permite en términos constitucionales el establecimiento del tipo de la justificación pública del genocidio (art. 607.2 CP). Tal comprensión de la justificación pública del genocidio, y siempre con la reseñada cautela del respeto al contenido de la libertad ideológica, en cuanto comprensiva de la proclamación de ideas o posiciones políticas propias o adhesión a las ajenas, permite la proporcionada intervención penal del Estado como última solución defensiva de los derechos fundamentales y las libertades públicas protegidas, cuya directa afectación excluye la conducta justificativa del genocidio del ámbito de protección del derecho fundamental a la libertad de expresión (art. 20.1 CE), de manera que, interpretada en este sentido, la norma punitiva resulta, en este punto, conforme a la Constitución».

Finaliza el juez constitucional su pronunciamiento previendo los efectos que su decisión interpretativa puede producir sobre el conjunto de la regulación penal antidiscriminatoria. Si en el FJ 7 el Tribunal, después de proclamar su legitimidad para dictar sentencias interpretativas, se planteó la posibilidad hipotética de que el art. 607.2 CP, considerado en su conjunto, pudiera ser conforme a la Constitución «si se pudiera deducir del mismo que la conducta sancionada implica necesariamente una incitación directa a la violencia contra determinados grupos o un menosprecio hacia las víctimas de los delitos de genocidio", allí advertía también de una dificultad añadida a la propia literalidad del precepto: ello privaría de autonomía a este delito en la medida que, interpretado en estos 
términos, la conducta típica coincidiría con la penalizada por el art. $615 \mathrm{CP}$ en relación con el art 18 (provocación, mediante la incitación directa, a la ejecución de un delito de genocidio) y por el art. $510 \mathrm{CP}$ y la inferior penalidad prevista en el art. 607.2 $\mathrm{CP}^{35}$ impediría apreciar una voluntad del legislador de configurar una modalidad cualificada de la apología del genocidio.

Siendo esto así, la interpretación del Alto Tribunal en el FJ 9 permite despejar las perplejidades de la Audiencia Provincial que argumentaba la imposibilidad de reconducir las conductas del art. 607.2 CP a la apología del genocidio penada en el art. 615 CP sobre la base de que el tipo del art. 607.2 no contemplaba la incitación directa (imprescindible para la punibilidad de la apología como forma de provocación ex art. 18.1 CP) y, por otra parte, sobre la desproporcionada levedad de la pena del art. 607.2 en comparación con la impuesta por el art. 615 CP. Si el art. 607.2 CP castiga la justificación pública del genocidio en cuanto incitación indirecta o provocación mediata, «la referida interpretación del art. 607.2 CP conforme a la Constitución no puede entenderse como desvirtuadora de la voluntad del legislador, pues dota al precepto de un ámbito punible propio y específico que, en aplicación del principio de proporcionalidad puede entenderse adaptado razonablemente en cuanto a las penas a la gravedad de las conductas perseguidas» y ello por cuanto lo que penaliza el precepto en cuestión es una conducta — la incitación indirecta - netamente diferenciada de la apología como incitación o provocación directa al genocidio (art. $615 \mathrm{CP}$ ) y de la provocación a la discriminación, al odio o a la violencia penada por el art. 510 CP; se trata, por tanto, de «una modalidad específica de incitación al delito que merece por ello una penalidad diferenciada, adaptada, según el criterio del legislador, a la gravedad de dicha conducta conforme a parámetros de proporcionalidad» y ello determina la mayor levedad de la pena prescrita.

\section{ALGUNAS CONSIDERACIONES CRÍTICAS}

\section{Clarificación limitada de la situación}

Es indudable que la STC 235/2007 ha venido a clarificar hasta cierto punto el estado de la cuestión en España, especialmente en lo que se refiere a la for-

$35 \mathrm{El}$ art. 607.2 CP prescribe una pena de de prisión de uno a dos años mientras que el art. 615 establece para la provocación al genocidio una pena inferior en uno o dos grados a la que corresponda a la modalidad concreta de genocidio de que se trate, estando sancionadas las distintas variantes del delito de genocidio en el art. 607.1 CP con penas entre 4 y 8 años.

(C) UNED. Revista de Derecho Político

N. ${ }^{\circ} 73$, septiembre-diciembre 2008, págs. 103-146 
ma más extrema del revisionismo histórico, esto es, la negación del Holocausto durante la Segunda Guerra Mundial.

$\mathrm{Al}$ declarar inconstitucional y nula la sanción penal de la difusión de ideas o doctrinas que nieguen los delitos de genocidio en el art. 607.2 CP se establece una certeza que acaba con las dudas que podían existir al respecto; por una parte las SSTC 214/1991 y 176/1995 permiten defender, en principio, la legitimidad constitucional de la discusión histórica en torno a la existencia del genocidio - a diferencia de la jurisprudencia del TEDH, como se ha vistopor cuanto, con independencia de la valoración que puedan merecer las tesis negacionistas, se trata de meras opiniones sobre hechos históricos que gozan de la cobertura de las libertades ideológica y de expresión; sin embargo, las dos sentencias (aunque en la 214/1991 sólo se discutió acerca de la protección civil del derecho al honor frente a las afirmaciones revisionistas) se refirieron a hechos anteriores a la penalización del negacionismo que arranca con la entrada en vigor de la Ley Orgánica 4/1995, de 11 de mayo, tras la cual el art. 137 bis b) del Código Penal de 1973 tipificó como apología del genocidio la exposición pública de ideas o doctrinas que nieguen, banalicen o justifiquen los actos genocidas o pretendan la rehabilitación o constitución de regímenes o instituciones que amparen prácticas generadoras del delito de genocidio, si bien siempre que tales conductas, por su naturaleza y circunstancias pudieran constituir una incitación directa a cometer delito. Posteriormente, a partir de la entrada en vigor del Código Penal de 1995 el art. 607.2 CP ha castigado la difusión de ideas o doctrinas negacionistas sin exigir ya, como sabemos, la concurrencia de la incitación directa $^{36}$. En consecuencia, la libertad de transmisión de ideas negacionistas al amparo del art. 20.1 CE y de la citada jurisprudencia constitucional tenía como límite insalvable la tipificación penal de dicha conducta, tipificación que desaparece como consecuencia del fallo de la STC 235/2007.

Suprimido así el límite penal al negacionismo, resulta evidente por obvia la cobertura constitucional al amparo de la libertad de expresión de aquellas manifestaciones revisionistas más moderadas en las que no se afirma radicalmente la inexistencia del Holocausto sino que se introducen dudas sobre ciertos aspectos del mismo o se discute si respondió a un plan deliberado de exterminio racial, tanto más cuando la STC 235/2007, por remisión a la 43/2004, ha destacado la mayor protección de la libertad científica respecto a las de expresión e

36 Señala J. M Tamarit Sumilla que «el tipo se consuma con la mera difusión pública de las referidas ideas. No se exige una voluntad de provocar el genocidio o una aprobación directa del mismo, sino que basta con que la ideología difundida preconice la implantación de un régimen que ampare tal práctica» («Artículo 607», cit., págs. 1641 y 1642). 
información para posibilitar una investigación histórica intrínsecamente polémica en la que la incertidumbre objetiva de los hechos enjuiciados es consustancial al debate ${ }^{37}$ (FJ 4). Evidentemente, la protección constitucional de las opiniones históricas revisionistas será tanto más clara cuanto más sea incardinable en una investigación ajustada a los presupuestos metodológicos de la ciencia histórica, pero no por ello dejarán de gozar de la cobertura constitucional de las libertades ideológicas y de expresión las simples afirmaciones de los profanos, cualquiera que sea su consistencia o fundamento.

En todo caso, la relevancia práctica de la despenalización del negacionismo será previsiblemente limitada por cuanto la misma se refiere a la difusión «neutra» de ideas negacionistas, desprovista de cualesquiera valoraciones que puedan ser incriminadas mediante alguno de los tipos penales conexos y, generalmente, salvo casos aislados y marginales de tesis negacionistas puras, asépticas o académicas desconectadas de postulados ideológicos racistas o filonazis. En la gran mayoría de los casos la negación del Holocausto se producirá en un contexto de expresiones subsumibles en justificación del genocidio, apología o provocación a la discriminación, al odio o a la violencia, conductas todas ellas que siguen penalizadas. El propio supuesto en el que se ha dictado la cuestión de inconstitucionalidad es buena prueba de ello: en la medida en que, según los hechos probados, el apelante es responsable de la difusión de material negacionista de tono vejatorio, justificativo o incitativo al genocidio, a la discriminación o al odio, la inconstitucionalidad parcial del art. 607.2 no priva de fundamento jurídico a su condena por otros tipos delictivos concurrentes (el art. 607.2 en la parte no afectada por la declaración de inconstitucionalidad o el art. 510.1 CP).

\section{Persistencia de la contradicción preexistente con el ámbito de la libertad ideológica}

Pese a lo anteriormente afirmado, la STC 235/1997 deja todavía un amplio margen de ambigüedad en la medida que, al confirmar los pronunciamientos

37 En este sentido la STC 43/2004 a la que se remite la sentencia comentada afirma que «si la historia solamente pudiera construirse con base en hechos incuestionables, se haría imposible la historiografía, concebida como ciencia social. En su ámbito, los historiadores valoran cuáles son las causas que explican los hechos históricos y proponen su interpretación, y aunque tales explicaciones e interpretaciones sean en ocasiones incompatibles con otras visiones, no corresponde a este Tribunal decidir, por acción u omisión, cuál o cuáles deban imponerse de entre las posibles. Son los propios ciudadanos quienes, a la luz del debate historiográfico y cultural, conforman su propia visión de lo acaecido, que puede variar en el futuro» (FJ 6). 
doctrinales de las SSTC 214/1991 y 176/1995, sigue subsistiendo, al menos en parte, la contradicción existente entre aquella jurisprudencia y la doctrina constitucional sobre las libertades de expresión e ideológica establecida en la STC 20/1990.

Como ya expusimos, las sentencias de 1991 y 1995 vinieron a afirmar que cualesquiera opiniones -incluso las equivocadas, peligrosas, agresivas hacia el sistema democrático y negadoras de la Constitución o afirmaciones reprobables o tergiversadas sobre los campos de concentración- están amparadas por las libertades ideológica y de expresión pero, al mismo tiempo, rechazaron que tales libertades puedan cobijar manifestaciones o expresiones que no respeten la dignidad, la igualdad y los valores superiores del ordenamiento jurídico; esta última afirmación de la eficacia limitativa de la dignidad y los valores superiores es difícilmente cohonestable con el entendimiento del ámbito de las libertades ideológica y de expresión con la «máxima amplitud», «no sólo en lo coincidente con la Constitución y con el resto del ordenamiento jurídico, sino también en lo que resulte contrapuesto a los valores y bienes que en ella se consagran, excluida siempre la violencia para imponer los propios criterios, pero permitiendo la libre exposición de los mismos en los términos que impone una democracia avanzada» (STC 20/1990, FJ 5).

Se mantiene, pues, aquella contradicción pero se plantea ahora mediante nuevas formulaciones y, en todo caso, debe reseñarse que la STC 235/2007 aporta nuevos elementos que pueden inclinar la balanza a favor de una interpretación que matice la eficacia limitativa de la dignidad y los valores superiores respecto de las libertades ideológica y de expresión.

a) Así, se dice en la sentencia objeto de análisis que «los derechos fundamentales [...] no pueden limitarse en razón de que se utilicen con una finalidad anticonstitucional [...]. El ámbito constitucionalmente protegido de la libertad de expresión no puede verse restringido por el hecho de que se utilice para la difusión de ideas u opiniones contrarias a la esencia misma de la Constitución y ciertamente las que se difundieron en el asunto que ha dado origen a la presente cuestión de inconstitucionalidad resultan repulsivas desde el punto de vista de la dignidad humana constitucionalmente garantizada - a no ser que con ellas se lesionen efectivamente derechos o bienes de relevancia constitucional» (FJ 4); en el mismo sentido, el Tribunal establece en el FJ 6 que "la mera transmisión de opiniones, por más deleznables que resulten desde le punto de vista de los valores que fundamentan nuestra Constitución» resulta amparada por las libertades de expresión, científica e ideológica, y que «nuestro ordenamiento constitucional no permite la tipificación como delito de la mera transmisión de ideas, ni siquiera en los casos en que se trate de ideas execrables por resultar con- 
trarias a la dignidad humana que constituye el fundamento de todos los derechos que recoge la Constitución y, por ende, de nuestro sistema político».

b) Sin embargo, las afirmaciones anteriores no eclipsan la relevancia que sigue otorgándose a la dignidad como límite de la libertad de expresión, no sólo por remisión a la doctrina ya comentada de las SSTC 214/1991 y 176/1995, sino mediante nuevas proclamaciones en este sentido: «el reconocimiento constitucional de la dignidad humana configura el marco dentro del cual ha de desarrollarse el ejercicio de los derechos fundamentales y en su virtud carece de cobertura constitucional la apología de los verdugos, glorificando su imagen y justificando sus hechos cuando ello suponga una humillación de sus víctimas» (STC 176/1995, FJ). Igualmente, hemos reconocido que atentan también contra este núcleo irreductible de valores esenciales de nuestro sistema constitucional los juicios ofensivos contra el pueblo judío que, emitidos al hilo de posturas que niegan la evidencia del genocidio nazi, suponen una incitación racista (STC 214/1991, de 11 de noviembre, FJ 8; 13/2001, de 29 de enero, FJ 7)» (FJ 5).

En consecuencia, aparentemente sigue existiendo la contradicción anteriormente expuesta, incrementada incluso en su crudeza al afirmarse expresamente que la libertad de expresión, no sólo puede ejercerse para una finalidad anticonstitucional sino que ampara las ideas u opiniones contrarias a la esencia misma de la Constitución aunque sean «repulsivas desde el punto de vista de la dignidad humana constitucionalmente garantizada», «deleznables [...] desde el punto de vista de los valores que fundamentan nuestra Constitución» o "execrables por resultar contrarias a la dignidad humana» (FFJJ 4 y 6). La existencia de esta contradicción ha sido advertida, con razón, por el voto particular del magistrado Rodríguez-Zapata al contraponer estas afirmaciones a las sentadas en las SSTC $214 / 1991$ y $176 / 1995^{38}$.

\section{Nuevos elementos a tener en cuenta}

Ahora bien, como antes hemos anticipado, la STC 235/1997, sin perjuicio de reproducir la contradicción que la doctrina constitucional sobre la materia

38 «La Sentencia de la mayoría considera que las ideas u opiniones que han dado origen a esta cuestión de inconstitucionalidad «resultan repulsivas desde el punto de vista de la dignidad humana constitucionalmente garantizada" (sic en FJ 4) pero ello no impide concluir que, al menos en parte, deben encontrar cobijo en una visión de la libertad de expresión del art. 20 CE de la que discrepo. Esta doctrina se contrapone a lo que declaramos en las SSTC 214/1991, de 11 de noviembre (Caso León Degrelle) y 176/1995, de 12 de enero (caso del cómic Hitler-SS) (ap. 2 del VP del magistrado Rodríguez-Zapata). 
viene arrastrando desde 1991, contiene simultáneamente algunas aportaciones que pueden fundamentar un enfoque que, cuanto menos, permita reducir la incertidumbre que genera la incongruencia en cuestión.

a) El primero de estos elementos es la remisión expresa a la STC 48/2003 para afirmar la improcedencia de aplicar en nuestro ordenamiento constitucional los cánones de una democracia militante o beligerante y la necesaria distinción entre dos niveles, las actividades o medios contrarios a la Constitución y las ideologías profesadas.

La STC 48/2003, a propósito del régimen jurídico de los partidos políticos, declaró que no es posible sostener que el sistema español responda a un modelo de «democracia militante» en la medida que ello sería incompatible con la posibilidad de postular la reforma de la Constitución sin exclusiones ratione materiae; si es constitucionalmente legítimo perseguir la reforma total de la Constitución, no puede ser ilegítimo discrepar de la misma siempre que tal voluntad reformadora se lleve a cabo respetando los procedimientos establecidos. En este sentido, se afirma que «falta para ello [para la existencia de un modelo de democracia militante que exija adhesión positiva a la Constitución] el presupuesto inexcusable de la existencia de un núcleo normativo inaccesible a los procedimientos de reforma constitucional que, por su intangibilidad misma, pudiera erigirse en parámetro autónomo de corrección jurídica, de manera que la sola pretensión de afectarlo convirtiera en antijurídica la conducta que, sin embargo, se atuviera escrupulosamente a los procedimientos normativos. [...] La Constitución Española, a diferencia de la francesa o la alemana, no excluye de la posibilidad de reforma ninguno de sus preceptos, ni somete el poder de revisión constitucional a más límites expresos que los estrictamente formales y de procedimiento. Ciertamente, nuestra Constitución también proclama principios, debidamente acogidos en su articulado, que dan fundamento y razón de ser a sus normas concretas. Son los principios constitucionales [...] Principios todos que vinculan y obligan, como la Constitución entera, a los ciudadanos y a los poderes públicos (art. 9.1 CE), incluso cuando se postule su reforma o revisión y hasta tanto ésta no se verifique con éxito a través de los procedimientos establecido en su Título X. Esto sentado, desde el respeto a esos principios, [...] cualquier proyecto es compatible con la Constitución, siempre y cuando no se defienda a través de una actividad que vulnere los principios democráticos o los derechos fundamentales» (FJ 7).

De lo anterior, unido a la declaración del Tribunal en la misma sentencia en el sentido de que las posibilidades de declaración de ilegalidad, disolución y suspensión judicial de los partidos políticos previstas en los arts. 9, 10 y 11 de la Ley Orgánica 6/2002, de 27 de junio, de Partidos Políticos se basan en las acti- 
vidades y conductas de los partidos y en ningún caso en sus fines, objetivos programáticos o ideología $^{39}$, concluye la STC 235/2007 «la necesidad de diferenciar claramente entre las actividades contrarias a la Constitución, huérfanas de su protección, y la mera difusión de ideas e ideologías. El valor del pluralismo y la necesidad del libre intercambio de ideas como sustrato del sistema democrático representativo impiden cualquier actividad de los poderes públicos tendente a controlar, seleccionar, o determinar gravemente la mera circulación pública de ideas o doctrinas» (FJ 4). En definitiva, no es la transmisión de ideas y doctrinas lo que vulnera la Constitución y sus principios sino los actos que no respetan sus principios y valores, en tanto estén vigentes.

b) Aunque en la STC 235/2007 el juicio de constitucionalidad se realiza mayoritariamente desde el prisma de la libertad de expresión del art. 20.1 a) CE - es éste el precepto al que se refiere la duda de constitucionalidad plateada por la Audiencia Provincial de Barcelona-, hay que tener en cuenta que se trata de un supuesto cualificado de ejercicio de la libertad de expresión como proyección o manifestación externa de la libertad ideológica, lo que, lejos de ser baladí, implica una mayor extensión del ámbito constitucionalmente protegido por la libertad de expresión respecto de los casos en los que no se da su concurrencia con la libertad ideológica. Ello no sólo se evidencia en las remisiones a la doctrina constitucional en las que se conectan ambas libertades (SSTC 20/1990, FFJJ 3, 4 y 5; 214/1991, FJ 8; 176/1995, FJ 2; y 48/20003, FFJ 7 y 10) sino en referencias expresas a que la conducta de difusión de ideas o doctrinas negacionistas está amparada por la libertad de expresión "e incluso eventualmente por las libertades científica [art. 20.1. b) y de conciencia (art. 16 CR) que se manifiestan a su través» (el subrayado es del autor, STC 235/1997, FJ 6)" así como en la interpretación conforme de la penalización de las conductas de difusión de ideas o doctrinas que justifiquen el genocidio que se realiza en el FJ 9, penalización que,

39 «En ningún momento se hace referencia a programas o ideologías sino a actividades de colaboración o apoyo al terrorismo o la violencia. En consecuencia, no se abre ningún resquicio a la que se ha llamado "democracia militante" y no hay, por consiguiente, vulneración alguna de las libertades ideológica, de participación, de expresión o de información. [...] Lo mismo cabe decir, en general, respecto a la previsión contenida en la letra c) del art. 10.2 LOPP: "Cuando de forma reiterada y grave su actividad vulnere los principios democráticos o persiga deteriorar o destruir el régimen de libertades o imposibilitar o eliminar el sistema democrático, mediante las conductas a que se refiere el art. 9". También aquí es necesario señalar que el precepto se circunscribe a la actividad de los partidos políticos, sin extenderse a sus fines u objetivos programáticos. Por tanto, en los términos de este precepto, sólo incurre en causa de disolución el partido que, no en su ideología, sino en su actividad persiga efectiva y actualmente "deteriorar o destruir el régimen de libertades"» (STC 48/2003, FJ 10). 
como se indicó, se declara constitucional «siempre que no se entienda incluida en ellas la mera adhesión ideológica a posiciones políticas de cualquier tipo, que resultaría plenamente amparada por el art. 16 CE y, en conexión, por el art. 20 CE» y « siempre con la reseñada cautela del respeto al contenido de la libertad ideológica, en cuanto comprensiva de la proclamación de ideas o posiciones políticas propias o adhesión a las ajenas».

Esta consideración de las conductas cuyo reproche penal se analiza como actos de ejercicio concurrente y simultáneo de las libertades ideológica y de expresión tiene una consecuencia lógica que el Tribunal no explicita en este caso, pero que se desprende de la jurisprudencia constitucional sobre la libertad ideológica: el ámbito de la libertad de expresión se expande cuando mediante ella se exterioriza la libertad ideológica. Es cierto que esta dilatación de la protección constitucional otorgada a la libertad de expresión ideológica debería operar mediante la aplicación del orden público como único límite en lugar de los límites que para la libertad de expresión se prevén en el art. $20.4 \mathrm{CE}^{40}$ y que en el presente caso, siguiendo una tendencia ya consolidada, el Tribunal no recurre a la claúsula de orden público para llevar a cabo esta interpretación expansiva ${ }^{41}$, pero permanece el sentido último de esta doctrina, la ampliación del ámbito de la libertad de expresión si ésta actúa como soporte de la libertad ideológica. Ello sin perjuicio de que la STC 235/2007 recurra a un argumento complementario para ensanchar el contenido protegido de la libertad de expresión: la "protección acrecida» de que goza la libertad científica del art. 20.1 b CE respecto a las de

40 «La libertad ideológica [...] por ser esencial [...] para la efectividad de los valores superiores y especialmente del pluralismo político, hace necesario que el ámbito de este derecho no se recorte ni tenga «más limitación (en singular utiliza esta palabra el art. 16.1 C.E.), en sus manifestaciones, que la necesaria para el mantenimiento del orden público protegido por la ley». La limitación, por la singularidad y necesidad con que se precisa en el propio precepto que la determina, no puede hacerse coincidente en términos absolutos [...], con los límites que a los derechos de libertad de expresión y de información reconocidos por el art. 20.1 a) y d) C.E., impone el núm. 4 de esta norma. La equiparación entre una y otras limitaciones, requiere, en todo caso, que, como ocurre en este supuesto, cuando el hecho imputado a un ciudadano afecte principalmente a su derecho a la libertad ideológica, su enjuiciamiento ha de ponderar y analizar también principalmente de qué manera a través de su manifestación externa se ha vulnerado el «orden público protegido por la Ley. [...] Trasladar todo el problema a los límites que señala el núm. 4 del art. 20 [...] a los derechos que se reconocen y protegen en los apartados a) y d) del núm. 1 de este artículo, se equipara en punto a limitaciones de la libertad ideológica con esos otros derechos fundamentales y por esta vía se restringe la mayor amplitud con que la Constitución configura el ámbito de aquel derecho » (STC 20/1990, FJ 3). Vid. al respecto G. ROLLNERT LIERN, La libertad ideológica..., cit., págs. 372-389).

41 Vid. G. Rollnert Liern, La libertad ideológica..., cit., págs. 389-397). 
expresión e información (FJ 8, remitiéndose a la STC 43/2004, FJ 4), libertad científica que en este supuesto se manifiesta también, al igual que la libertad ideológica, a través del derecho a la libertad de expresión (FJ 6); pero, lógicamente, esta mayor protección de la libertad de expresión científica del historiador sólo existirá cuando sea propiamente encuadrable «en el ámbito de la investigación histórica y, por tanto, en el terreno científico, [...] cuando efectivamente se ajuste a los usos y métodos característicos de la ciencia historiográfica ${ }^{42}{ }_{\gg}$ (FJ 5).

La imbricación de la libertad ideológica con la libertad de expresión en las manifestaciones revisionistas añade otro elemento a tener en cuenta, cual es la imposibilidad de restringir preventivamente la libertad ideológica si no se acredita la existencia de riesgos concretos objetivos. Aunque esta doctrina la ha sentado el Tribunal Constitucional con relación a la aplicación preventiva de la claúsula del orden público para limitar la libertad religiosa ${ }^{43}$, el régimen jurídico común de esta última libertad con la libertad ideológica permite hacer extensiva la misma a los casos de doble adscripción de una conducta a las libertades ideológica y de expresión. En este sentido, cabe señalar que la STC 235/2007 despenaliza precisamente la mera negación del genocidio por entender que no puede restringirse tan radicalmente la libertad de expresión con fundamento en una conducta - la negación del genocidio- que sólo de forma preventiva o cautelar puede crear un riesgo de generación de un clima social de animosidad contra las víctimas, considerando que no constituye siquiera un ries-

42 En este caso la STC 43/2004 le atribuye prevalencia sobre el derecho al honor de las personas fallecidas afectadas por la investigación, prevalencia que basa en que la personalidad de los fallecidos «se ha ido diluyendo necesariamente como consecuencia del paso del tiempo y no puede oponerse, por tanto, como límite a la libertad científica con el mismo alcance e intensidad con el que se opone la dignidad de los vivos al ejercicio de las libertades de expresión e información de sus coetáneos» y, por otra parte, en que la naturaleza científico-histórica de la actividad desarrollada supone de por sí «un reforzamiento de las exigencias requeridas por el art. $20 \mathrm{CE}$ en punto a la veracidad de la información ofrecida por el investigador, esto es, a su diligencia» (FJ 5).

43 En este sentido, el Tribunal Constitucional ha declarado que cabe la utilización preventiva excepcional de la cláusula del orden público si «se ha acreditado en sede judicial la existencia de un peligro cierto para «la seguridad, la salud y la moralidad pública», tal como han de ser entendidos en una sociedad democrática» y que, además, la medida adoptada sea proporcionada y adecuada a los fines perseguidos (STC 46/2001, FJ 10 remitiéndose a las SSTC 120/1990, de 27 de junio, 137/1998, de 29 de junio, y 141/2000, de 29 de mayo; STEDH casos Kokkinakis, Hoffmann y C.R. c. Suiza)». Con anterioridad, la STC 141/2000 ya había anticipado la idea de que el límite del orden público sólo puede ser aplicado a la libertad de creencias cuando existan riesgos concretos para el orden público, acreditables de forma objetiva y no deducidos por conjetura a partir de las creencias personales, imponiendo al mismo tiempo a los poderes públicos la carga de justificar cualquier restricción que se imponga a los derechos del arts. 16.1, restricciones que en todo caso deberán cumplir el requisito de la proporcionalidad. 
go potencial para el bien jurídico protegido; y que, por otra parte, ampara la constitucionalidad de la punición de la difusión pública de las ideas que justifiquen el Holocausto sobre la base de considerar que tal conducta, en cuanto sea constitutiva de una incitación indirecta a la comisión de delitos de genocidio o persiga la provocación al odio hacia determinados grupos, representa «un peligro cierto de generar un clima de violencia y hostilidad que pueda concretarse en actos específicos de discriminación» (FJ 9).

Finalmente, las referencias a la libertad ideológica como límite a la posibilidad de sancionar penalmente en el art. 607.2 CP la difusión de ideas o doctrinas que justifiquen los delitos de genocidio exigen traer a colación los pronunciamientos del Tribunal Constitucional acerca de las posibles violaciones de la libertad ideológica ${ }^{44}$, del tal manera que será inconstitucional aquella interpretación del art. 607.2 CP que, por una parte, perturbe o impida objetivamente la simple expresión de posiciones políticas, por muy radicales y anticonstitucionales que puedan ser, $y$, por otra, que tenga por causa precisamente el sostenimiento de unas determinadas ideas o creencias. La aplicación del art. 607.2 CP para sancionar la difusión pública del genocidio deberá ser, por tanto, muy cuidadosa evitando su utilización como mecanismo de criminalización de opciones políticas socialmente consideradas indeseables, lo que sucedería si se empleara para fundamentar condenas penales basadas en juicios de intenciones o en presunciones de asociación de determinadas posturas políticas con la justificación del Holocausto. Dicho en otras palabras, la libertad ideológica impide aplicar el art. 607.2 CP a alguien que se declare nazi por mera asociación de la profesión de nazismo con la justificación del Holocausto; podrá ser condenado por unas actividades concretas de difusión que le sean personalmente imputables en las que justifique el Holocausto, pero no cabe presumir que, por ser nazi, incurre per se en el delito de justificación del genocidio sobre la base de que la ideología nazi está necesariamente asociada a tal justificación, con independencia de que empírica y estadísticamente exista esta correlación.

44 «[...] Para que los actos de los poderes públicos puedan ser anulados por violaciones de la libertad ideológica reconocida en el artículo 16.1 CE es cuando menos preciso, de una parte, que aquellos perturben o impidan de algún modo la adopción o el mantenimiento en libertad de una determinada ideología o pensamiento y no simplemente que se incida en la expresión de determinados criterios — por más que ello pueda tener relevancia ex artículo 20.1 CE- De otra, se exige que entre el contenido y sostenimiento de éstos y lo dispuesto en los actos que se combatan quepa apreciar una relación de causalidad suficiente para articular la imputación del ilícito constitucional» (STC 120/1990, de 27 de junio, FJ 10). Sobre las violaciones de la libertad ideológica, vid. G. ROLLnERT Liern, La libertad ideológica..., cit., págs. 132-141). 


\section{Criterios para el enfoque de la cuestión}

Pues bien, teniendo en cuenta lo afirmado en los anteriores apartados 3, a) y b)i, puede decirse que en la STC 235/2007, bien por afirmación explícita, bien por remisión a otros pronunciamientos del Alto Tribunal, el Tribunal Constitucional ha dado algunos criterios para superar una confusión subyacente en las sentencias 214/1991 y 176/1995 a la que ya hemos tenido ocasión de hacer referencia en otras ocasiones ${ }^{45} \mathrm{y}$ en las que se encontraría el origen de la contradicción señalada.

Si se analizan con detenimiento estas sentencias se observara que en ellas se sigue el mismo proceso discursivo: partiendo de la máxima amplitud de la libertad ideológica, se rechaza que la misma ampare, sin embargo, manifestaciones ofensivas y xenófobas por ser las mismas constitutivas de una incitación al odio racial, a la discriminación o a la violencia. El razonamiento del juez constitucional es, en este aspecto, impecable. Lo que a nuestro juicio es criticable es la equiparación entre las expresiones injuriosas, apologéticas del genocidio o incitativas al odio a la violencia o a la discriminación, indudablemente situadas fuera de la protección constitucional, y aquellas otras manifestaciones, también contrarias a la igualdad o a otros valores constitucionalmente protegidos, pero que no lleguen a incurrir en la ofensa, la incitación (directa o indirecta) o la apología del odio racial, la violencia o el genocidio.

Esta confusión presente en ambas sentencias entre la ofensa a una etnia, la incitación o provocación al genocidio, a la discriminación, al odio racial y a la violencia - que en ningún caso pueden gozar de la protección constitucional a la libertad ideológica y a la libertad de expresión-y, de otro lado, la expresión de convicciones contrarias a determinados valores en la formulación constitucionalmente acogida, es la que, a nuestro juicio, explica la contradicción con la doctrina anteriormente establecida en la STC 20/1990 y que puede ser superada o, cuanto menos, amortiguada con la reciente sentencia de 7 de noviembre de 2007.

En esta distinción se encuentra la clave para una interpretación superadora de la aparente contradicción de la doctrina constitucional. La expresión pacífica de posiciones ideológicas inspiradas en valores contrarios a los consagrados constitucionalmente no deja de gozar de la protección constitucionalmente dispensada a las libertades ideológica y de expresión que, en otro caso, quedarían vaciadas de todo contenido efectivo. Las declaraciones o afirmaciones que

${ }^{45}$ G. Rollnert Liern, Los limites..., cit., págs. 263-266. 
puedan ser contrarias, por ejemplo, a la igualdad y a la dignidad humana fundada en la misma no suponen en sí mismas una vulneración del deber de respeto a la Constitución y al resto del ordenamiento jurídico (art. 9.1 CE) y ello por cuanto ese mismo ordenamiento permite perseguir legítimamemente la reforma constitucional y, lógicamente, la revisión o reformulación de sus propios valores superiores respetando los procedimientos de reforma previamente establecidos.

Las actitudes, las ideas, los pensamientos, por muy radicalmente enfrentados que estén con el orden constitucional, en ningún caso lo vulneran salvo cuando postulan la violencia como forma de acción política o se traducen en actos o comportamientos concretos que lesionan derechos ajenos tales como el honor individual o colectivo de otros miembros de la comunidad o incurren en los delitos de apología del genocidio por incitación directa a su comisión (arts. 615 y $18 \mathrm{CP}$ ) provocación al odio, a la discriminación o a la violencia (art. 510.1 CP) o difusión de ideas o doctrinas justificadoras del genocidio o rehabilitadoras de los regímenes que amparen prácticas genocidas (art. 607.2 CP en la parte no afectada por la declaración de inconstitucionalidad). La vigencia de los valores superiores del ordenamiento jurídico no es vigencia ideológica en el sentido de incuestionabilidad teórica sino vigencia jurídica en el sentido de no poder ser desconocidos o vulnerados por los actos y comportamientos de los ciudadanos en virtud de la normatividad constitucional declarada en el art. 9.1 CE.

En consecuencia, un ciudadano podrá rechazar ideológicamente tales valores y expresar públicamente su rechazo — con los límites del respeto a los derechos ajenos y los límites penales anteriormente señalados- pero en ningún caso deja de estar obligado a ajustar su comportamiento a los mismos en su condición de ciudadano y también, en su caso, como titular de un cargo público. Es en este sentido como parece que debe ser interpretada la declaración del Tribunal en la STC 173/1995, de 21 de noviembre, en virtud de la cual «las ideas políticas y las adscripciones correspondientes son siempre legítimas con tal de que respeten los principios del Estado de Derecho establecidos por nuestra Ley fundamental» (FJ 5), respeto que debe entenderse como formal-procedimental y en ningún caso como vinculación ideológica a los mismos, tanto más cuando ni siquiera los titulares de cargos públicos vienen obligados a una adhesión ideológica a los valores constitucionales más allá de la traducción de los mismos en normas jurídicas concretas vinculantes para la totalidad de los ciudadanos ${ }^{46}$.

46 A este respecto, comentando las SSTC 101/1983, de 18 de noviembre; 122/1983, de 16 de diciembre; y 119/1990, de 21 de junio, G. ROLLnerT LIERn, La libertad ideológica, cit., págs. 216-233. 
A partir de esta distinción, puede reformularse la doctrina del Tribunal Constitucional en el sentido de que la libre expresión de ideas y valores contrarios a la $\mathrm{CE}$ tiene como límite, por un lado, la utilización de la violencia y, por otro lado, el derecho al honor - respecto de las expresiones ofensivas o injuriosas- y los tipos penales que incriminan en sus distintas variantes la incitación o provocación al odio, a la discriminación o a la violencia. De conformidad con la interpretación que se postula, en los dos supuestos de hecho contemplados por las sentencias 214/1991 y 176/1995, la ilegitimidad constitucional de las declaraciones y expresiones efectuadas traería causa, no de su incompatibilidad ideológica con los valores constitucionales de igualdad y dignidad ${ }^{47}$ sino de su valoración por el Tribunal como ofensivas e incitativas al odio, discriminación y violencia racial.

Lo dicho no significa que la dignidad, los valores superiores y los derechos de los demás no sean un límite a las libertades ideológica y de expresión. Lo son, como no podía ser de otra manera, pero en la medida en que padezcan una lesión efectiva; la dignidad no sufre, desde un punto de vista constitucional, por ataques o cuestionamientos puramente teóricos o ideales a la misma sino por actos, por comportamientos que afecten lesivamente a los concretos derechos de los que constituye principio y fundamento.

En este sentido, afirma la STC 235/2007 que «fundamentada en la dignidad (art. 10.1 y 2 CE) es, pues, el deliberado ánimo de menospreciar y discriminar a personas o grupos por razón de cualquier condición o circunstancia personal, étnica o social el que, en estos casos, priva de protección constitucional a la expresión y difusión de un determinado entendimiento de la historia o concepción del mundo que, de no ser por ello, podría encuadrarse en el ámbito constitucionalmente garantizado por el art. 20.1 CE» (FJ 5); aunque esta formulación no es muy afortunada (por cuanto la referencia al «ánimo» puede interpretarse como un juicio de intenciones pro futuro), situando esta afirmación en el contexto global de la sentencia, puede colegirse que sólo en la medida que hay actos efectivos de menosprecio y discriminación de personas y grupos, la dignidad puede limitar las libertades ideológica y de expresión ${ }^{48}$. Caben, pues, en la li-

47 En contra, M. Martínez Sospedra, ob. cit., págs. 5786 y 5796.

48 En este sentido, el Auto de 14 de septiembre de 2000 por el que la Sección Tercera de la Audiencia Provincial de Barcelona se planteó la cuestión de inconstitucionalidad afirma que «es el menosprecio a la dignidad de las personas y la puesta en peligro de la convivencia pacifica entre todos los ciudadanos, por la realización de actos discriminatorios contra las minorías, lo que no puede estar amparado por la libertad de expresión, y justifica la sanción penal de estas conductas» (apartado quinto). 
bertad de expresión, como se dice expresamente, opiniones abiertamente anticonstitucionales, «repulsivas», «deleznables» o «execrables» por contrarias a la dignidad humana, pero en ningún caso el insulto, la humillación o la incitación o provocación al genocidio, el odio, la violencia o la discriminación; «el amplio margen que el art. 20.1 CE ofrece a la difusión de ideas, acrecentado, en razón del valor del diálogo plural para la formación de una conciencia histórica colectiva, cuando se trata de la alusión a hechos históricos (STC 43/2004, de 23 de marzo), encuentra su límite en las manifestaciones vilipendiadoras, racistas o humillantes o en aquellas que incitan directamente a dichas actitudes, constitucionalmente inaceptables». La declaración del FJ 4 es contundente al respecto, la dignidad no limita en abstracto la difusión de ideas contrarias a la Constitución sino en cuanto haya lesión efectiva, en el plano de los actos, de derechos concretos de los terceros ${ }^{49}$.

Por otra parte, la descripción de las actividades a cuya incitación indirecta es constitucionalmente legítimo anudar una sanción penal mediante la tipificación delictiva de la justificación del genocidio en el art. 607.2 CP por afectar a la dignidad, evidencia claramente la forma en que la dignidad puede verse efectivamente lesionada, a diferencia de la mera transmisión de ideas o doctrinas negacionistas que, por ausencia de dicha lesión, es declarada inane por el juez constitucional: «la incitación indirecta a la comisión de algunas de las conductas tipificadas en el art. 607.1 CP como delito de genocidio - entre las que se incluyen entre otras el asesinato, las agresiones sexuales o los desplazamientos forzosos de población - cometidas con el propósito de exterminar a todo un grupo humano, afecta de manera especial a la esencia de la dignidad de la persona, en cuanto fundamento del orden político (art. $10 \mathrm{CE}$ ) y sustento de los derechos fundamentales. Tan íntima vinculación con el valor nuclear de cualquier sistema jurídico basado en el respeto a los derechos de la persona permite al legislador perseguir en este delito modalidades de provocación, incluso indirecta, que en otro caso podrían quedar fuera del ámbito del reproche penal» (FJ 9).

49 «El ámbito constitucionalmente protegido de la libertad de expresión no puede verse restringido por el hecho de que se utilice para la difusión de ideas u opiniones contrarias a la esencia misma de la Constitución - y ciertamente las que se difundieron en el asunto que ha dado origen a la presente cuestión de inconstitucionalidad resultan repulsivas desde el punto de vista de la dignidad humana constitucionalmente garantizada - a no ser que con ellas se lesionen efectivamente derechos o bienes de relevancia constitucional» (STC 235/2007, FJ 4). 


\section{Resumen}

Después de plantear la contradicción existente en la jurisprudencia constitucional que, por una parte, admite el revisionismo histórico con el límite del respeto a la dignidad y, por otra parte, reconoce con la máxima amplitud la libertad ideológica, se analiza la STC 235/2007 que ha declarado inconstitucional el delito de negación del genocidio y, en cambio, ha considerado constitucional la penalización de la justificación del genocidio. Esta sentencia ha clarificado parcialmente la situación del revisionismo histórico y, en general, de la difusión de ideas contrarias a la Constitución pero sigue existiendo aquella contradicción; no obstante, ha aportado elementos como la distinción entre ideas y actividades y la ampliación del ámbito de la libertad de expresión por su conexión con la libertad ideológica que permiten defender una interpretación de la jurisprudencia constitucional que considere protegidas por las libertades de expresión e ideológica las expresiones contrarias a la Constitución, porque la dignidad y los derechos de los demás sólo se ven lesionados por afirmaciones ofensivas o actividades o comportamientos violentos o discriminatorios y no por la simple expresión de ideas.

\section{Title}

Historical revisionism and racism in the constitutional case-law: the limits of the freedom of speech (apropos of the judgement of the constitutional court 235/2007).

\section{Summary}

I. Introduction and background: the maximum range of freedom of thought and the constitucional judgments 214/1991 and 176/1995. II. The constitutional judgmenst 235/2007 and its argumental lines: 1. The constitutional doctrine about freedom of speech and the rejection of «militant democracy». 2. The limits of the free comunication of ideas: "hate speech» and the applicability of art. 17 of the European Convention on Human Rights with special reference to the Strasbourg case-law about historical revisionism and racism. III. Conclusions of the judgment 235/2007: 1. The incidence of the crimes of art. 607.2 of the Penal Code on freedom of expression. 2. The inanity of the mere denial of the genocide. 3 . The constitutionality of criminal sanction of the justification of genocide: an interpretative judgment. IV. Some critical considerations: 1 . Limited clarification of the situation. 2. Persistence of the contradiction existing in the scope of freedom of thought. 3. New elements to be taken into account. 4. Criteria for the approach to the issue. 


\begin{abstract}
After noting the contradiction that exists in constitutional case-law that while accepting historical revisionism with the limitation of respecting dignity, at the same time recognizes the greatest extent of the freedom of thought, analyses Constitutional Judgement 235/2007 which declares the denial of genocide as a crime to be unconstitutional, but considers the penalization of the justification of genocide to be constitutional. This sentence has partially clarified the status of historical revisionism and, in general, the dissemination of ideas contrary to the Constitution, but the contradiction still remains; nevertheless, it has furnished elements such as the distinction between ideas and activities, and broadening the scope of the freedom of speech by connecting it to the freedom of thought that allows the defence of an interpretation of the constitutional case-law that considers the freedoms of speech and thought for expressions adverse to the Constitution to be protected, since the dignity and the rights of others are violated by offensive assertions, or violent or discriminatory activities or behaviour but not by the mere expression of ideas.
\end{abstract}

\title{
Palabras clave
}

libertad de expresión - libertad ideológica - revisionismo histórico - racismo - dignidad.

\section{Key words}

freedom of speech - freedom of thought - historical revisionism - racism - dignity. 